IZA DP No. 7167

Why Did the Netherlands Develop so Early?

The Legacy of the Brethren of the Common Life

i. Semih Akçomak

Dinand Webbink

Bas ter Weel

January 2013 


\title{
Why Did the Netherlands Develop So Early? The Legacy of the Brethren of the Common Life
}

\author{
i. Semih Akçomak \\ Middle East Technical University \\ Dinand Webbink \\ Erasmus University Rotterdam, CPB and IZA \\ Bas ter Weel \\ $C P B$, Maastricht University and IZA
}

\author{
Discussion Paper No. 7167 \\ January 2013
}

IZA
P.O. Box 7240
53072 Bonn
Germany

Phone: +49-228-3894-0
Fax: +49-228-3894-180
E-mail: iza@iza.org

Any opinions expressed here are those of the author(s) and not those of IZA. Research published in this series may include views on policy, but the institute itself takes no institutional policy positions. The IZA research network is committed to the IZA Guiding Principles of Research Integrity.

The Institute for the Study of Labor (IZA) in Bonn is a local and virtual international research center and a place of communication between science, politics and business. IZA is an independent nonprofit organization supported by Deutsche Post Foundation. The center is associated with the University of Bonn and offers a stimulating research environment through its international network, workshops and conferences, data service, project support, research visits and doctoral program. IZA engages in (i) original and internationally competitive research in all fields of labor economics, (ii) development of policy concepts, and (iii) dissemination of research results and concepts to the interested public.

IZA Discussion Papers often represent preliminary work and are circulated to encourage discussion. Citation of such a paper should account for its provisional character. A revised version may be available directly from the author. 


\section{ABSTRACT \\ Why Did the Netherlands Develop so Early? The Legacy of the Brethren of the Common Life}

This research provides an explanation for high literacy, economic growth and societal developments in the Netherlands in the period before the Dutch Republic. We establish a link between the Brethren of the Common Life (BCL), a religious community founded by Geert Groote in the city of Deventer in the late fourteenth century, and the early development of the Netherlands. The BCL stimulated human capital accumulation by educating Dutch citizens without inducing animosity from the dominant Roman Catholic Church or other political rulers. Human capital had an impact on the structure of economic development in the period immediately after 1400 . The educated workforce put pressure on the Habsburg monarchy leading to economic and religious resentment and eventually to the Revolt in 1572 . The analyses show that the BCL contributed to the high rates of literacy in the Netherlands. In addition, there are positive effects of the BCL on book production and on city growth in the fifteenth and sixteenth century. Finally, we find that cities with BCL-roots were more likely to join the Dutch Revolt. These findings are supported by regressions that use distance to Deventer as an instrument for the presence of BCL. The results are robust to a number of alternative explanations.

JEL Classification: N33, N93, O15, J20

Keywords: economic development, literacy, religion, societal change

Corresponding author:

Bas ter Weel

CPB Netherlands Bureau for Economic Policy Analysis

PO Box 80510

2508 GM The Hague

The Netherlands

E-mail: b.ter.weel@cpb.nl

\footnotetext{
* We would like to thank Daron Acemoglu, Joshua Angrist, Lex Borghans, Maarten Bosker, Raouf Boucekkine, Robin Cowan, David de la Croix, Casper van Ewijk, Oded Galor, Anne Gielen, Joop Hartog, Douglas Irwin, Rahmi Ilkilic, Frank Kleijbergen, Meir Kohn, Erzo F.P. Luttmer, Stelios Michalopoulos, Nathan Nunn, Christopher Palmer, Nina Pavcnik, Jon Skinner, Doug Staiger, Coen Teulings, David Weil and Jan Luiten van Zanden for helpful comments. Seminar participants at the Brown University, CPB, Dartmouth College, Erasmus University, Louvain-la-Neuve, Maastricht University, MIT, Utrecht University are also gratefully acknowledged for their feedback. Jelte Haagsma provided excellent research assistance. Finally, we thank Erika Kuijpers, Kees Mandemakers, Marco Mostert, Ad Notten, Nico Rasters and Martijn Smit for help with the obtaining the data and for historical information about the late medieval period in Northern Europe.
} 
"Nowhere else does one find a greater number of people of average education."

Desiderius Erasmus (cited in Cipolla, 1969, p. 47)

"Spanish visitors ... noted the widespread literacy in the Netherlands. One of Prince Philip's entourage, Vicente Alvarez, noted in his journal that 'almost everyone' knew how to read and write, even women ..."

From the notes of Philip's visit to the Netherlands in 1549 (Parker, 1977, p. 21)

\section{Introduction}

The Dutch Republic became an important economic power after a successful Revolt against the Habsburg rulers in the late sixteenth century (e.g., Israel, 1995). This successful development has for a large part been attributed to trade via the Atlantic Ocean and the emergence of political institutions that provided secure property rights to broader segments of society (e.g., Acemoglu et al. 2005). However, the early developments that led to these modern institutions and the rise of the Dutch Republic are not well understood. For instance, the levels of literacy were almost two times those of Germany at the end of the sixteenth century. These high levels of literacy in the Netherlands have also been documented by early visitors - as the quotes above suggest — and found in historical research (e.g., Cipolla, 1969, Parker, 1977, Baten and Van Zanden, 2008 and Buringh and Van Zanden, 2009). In addition, the period 1300-1500 has been labeled as a period of crisis in Europe, but not for the Netherlands (e.g., De Vries and Van der Woude, 1997). While the surrounding regions such as the Rhineland and Flanders, with urban giants as Cologne, Ghent and Bruges flourished already in the early 1300s, modern structures emerged in the Dutch economy from the end of the fourteenth century onwards. The result was rapid urbanization, industrialization of production in cities (e.g., textile production, brewing and shipbuilding) and rural areas (e.g., brick production). Eventually, it led to a Revolt against the Habsburg rulers in 1572, which led to the formation of the Dutch Republic in 1588. This marked the start of the Dutch Golden Age until 1702, when William III's death brought an end to the Dutch House of Orange (e.g., Israel, 1995).

The first episode of Dutch development in the period of about 1400 up to the Dutch Revolt - which is the period before the rise of Atlantic trade and before the Dutch East India Company was formed and became influential — is not well understood. The process of early economic and societal development was different in nature from the development that took place after the formation of the Dutch Republic in 1588. This paper establishes that the origin of the early modern structures can be linked to the Brethren of the Common Life (BCL), a 
religious community that stimulated the accumulation of human capital and provided the intellectual foundation for Christian Humanism throughout Europe. We develop a mechanism that explains the fundamental role of the BCL in the origin of the rise of the Netherlands and provide historical and empirical evidence consistent with the implications of our mechanism.

Our mechanism to explain early economic and societal development in the Netherlands can be summarized as follows. The BCL were a religious community founded by Geert Groote (1340-1384) in the city of Deventer in 1374. Groote was dissatisfied with the moral decline in the Roman Catholic Church. He believed that religion was a personal matter. Therefore, religious people should be able to read the Bible, other religious books and collections of sermons. He founded the BCL within the Church to start an inside reform. He was not motivated by a desire to increase prosperity or to change society.

The BCL stimulated the accumulation of human capital among civilian people through vernacular (religious) texts, schools and the production of books. This increased the literacy rate of the Dutch population substantially. By 1600 literacy rates in the Netherlands were higher compared to surrounding regions. At the same time, economic activity was stimulated by this early literacy which led to a rise of economic development. Finally, the BCL followed a socially inclusive approach when educating citizens. They operated within the Roman Catholic Church, but emphasized people's own responsibility for making a living. This way, the BCL laid the intellectual foundation for Christian Humanism, which is considered one of the most profound cultural changes in Western history. ${ }^{1}$ The early development and diffusion of Christian Humanism in the Netherlands provoked severe repression by the Habsburg rulers. This repression seems to be the most fundamental factor for the Dutch Revolt. ${ }^{2}$

To empirically establish a link between the BCL and the early development of the Netherlands, we focus on a number of early economic and societal outcomes. We analyze the impact of the BCL by focusing on differences across a sample of Dutch cities in the late medieval period and early Renaissance. First, we study the impact on two indicators of human capital: literacy rates and book production. We examine whether the early high rates of literacy in the Netherlands are associated with the BCL. The data on literacy rates at the

\footnotetext{
${ }^{1}$ Blockmans (1993) and Israel (1995) provide an overview of the development of Christian Humanism in Europe. In Section 2 we elaborate the link between the BCL and Christian Humanism.

${ }^{2}$ Israel (1995) labels the violent repression and strong measures as a mental civil war of the Habsburg Rulers against Dutch citizens. We elaborate on the effects of suppression in Section 2.
} 
end of the sixteenth century come from the Amsterdam archives and are the oldest data that enable an assessment of local differences in literacy in the Netherlands (e.g., Hart, 1976). We investigate the relationship between the presence of the BCL and local differences in literacy rates in 1600. In addition, we examine the relationship between the BCL and the production of books at the city-level in the period 1470-1500, which is the period immediately after the invention of the movable type printing press in Mainz. Second, we study the impact of the BCL on economic prosperity by investigating the relationship between the BCL and city growth (1400-1560). Third, we examine the relationship between the BCL and the Dutch Revolt in the second half of the sixteenth century. The Dutch Revolt started on 1 April 1572 when about 600 rebels took the small city of Brielle. In the next months many cities revolted against the Spanish rulers. We investigate whether the presence of the BCL is associated with the likelihood of joining the Revolt in Dutch cities. This serves as an indicator for dissatisfaction with the Habsburg rulers. Figure 1 presents a map that marks the borders of the geographical area of our study. The area we focus on is to the west of the river Eems and to the north of the Rhine, with the exception of a few cities in Brabant and Zeeland. Throughout this paper we refer to the geographical area as the Netherlands.

To document the association between the BCL and the economic and societal outcomes in the fifteenth and sixteenth century we use OLS estimators. We then attempt to establish a causal relationship between the BCL and the economic and societal outcomes by using instrumental variables techniques. The instrument we use is the distance to Deventer, the city where Geert Groote founded the BCL and many influential Christian Humanists — such as Desiderius Erasmus and Pope Adrian IV — attended school. ${ }^{3}$ Our estimates show that distance to Deventer is associated with the economic and societal outcomes after 1400, but not with the presence of schools before 1400 or with city growth before 1400 . We also find that after the Dutch Revolt the direct influence of the BCL on economic development disappeared.

Our estimates suggest a positive relationship between the BCL and the accumulation of human capital at the city level. The rate of literacy and the number of new book editions are higher in cities where the BCL were present. In addition, we find that cities in which the BCL were active have experienced stronger population growth in the period 1400-1560. Moreover, BCL-presence is associated with involvement in the Dutch Revolt. Cities in which the BCL

\footnotetext{
${ }^{3}$ In Section 2 we present the network of education and influence of the BCL by showing that influential thinkers and educators in the late medieval period in Europe can be linked to the BCL.
} 
had been present were more likely to join the rebellion than other cities. All associations are robust for various specifications and the inclusion of other religious movements and monastic orders in this period. We also find evidence that these associations can be considered as causal relationships. The instrumental variable estimates, using distance to Deventer as an instrument, corroborate the OLS estimates.

We address the robustness of our results in a number of different ways. Next to the analyses of educational efforts and city growth before 1400, we conduct five robustness checks. First, a placebo test in which we use distance to other important cities of that time as instruments does not establish a consistent link between the BCL and outcomes. Second, when we control for hanseatic trade we find a strong independent effect of the BCL on outcomes. Third, we investigate the impact on outcomes of the presence of other religious orders and find no effects. We also extend the geographical area beyond the Netherlands by adding information about cities in Belgium and Germany and obtain estimates that suggest a causal link between city growth and BCL-presence. Finally, we find that economic development during and after the Dutch Golden Age is of a different nature (e.g., Acemoglu et al., 2005). There is no significant relationship between the BCL and economic development after 1600. This is consistent with the interdiction imposed on all religious communities — including the BCL — that did not adopt monastic rules by Pius V in 1568. In the Netherlands this coincided with the Revolt and the Reformation (e.g. Slechte, 2010). Hence, we conclude that the BCL had an impact on the economic and societal jump start of the Netherlands in the period 1375 up to the formation of the Dutch Republic in 1588. It should be noted that we do not claim that the BCL is the only factor that determined the successful transformations of Dutch society. The success of BCL should be interpreted in the context of a society in which industrialization, trade and urbanization took off and in which the demand for human capital increased. The BCL was important for the supply of human capital and removed bottlenecks in human capital formation. As such, the BCL speeded up the production of human capital and the growth of the cities.

Our work contributes to the literature in economics. We empirically demonstrate the impact of religious orders on early economic development. Recent work by Becker and Woessmann (2009) and Cantoni (2012) examines the impact of the Reformation of 1517 and the subsequent rise of Protestantism on economic development. Becker and Woessmann find that Protestantism led to higher prosperity in Prussia through increased literacy rates. Cantoni (2012) finds no effects of Protestantism on economic development in European cities. Like 
Becker and Woessmann we emphasize the channel of human capital accumulation, but the BCL started 150 years before the Reformation. This offers an explanation for the jump start of the Netherlands. Both Becker and Woessmann and Cantoni analyze the effects up to 1900 but, as Cantoni (2012) shows, it seems a rather long shot to explain almost 400 years of European history by the direct effects of the Reformation. We are able to document the early effects of the BCL on economic development leading to economic and societal change in a period of about 200 years. Research by Barnebeck Andersen et al. (2011) examines the impact of the Cistercians on economic development in England in the period 1377-1801. The Cistercians did not emphasize the accumulation of human capital, like the BCL did. Rather, they stressed the importance of hard work and thrift. This led to a return to hard manual labor and the restrain from consumption. Barnebeck Andersen et al. (2011) argue that this induced cultural change, which influenced local cultural values, which subsequently took hold in the population of England. These new values in turn stimulated pre-industrial growth. We emphasize the direct effect of the BCL on human capital accumulation and find no effects of Cistercians or other religious orders on the early economic development of the Netherlands. Botticini and Eckstein (2007) study the transformation of Judaism at the beginning of the first millennium and find that this is driven by preferences, which is consistent with Geert Groote's initial motivation. Finally, Glaeser and Glendon (1998), Barro and McCleary (2005) and McCleary and Barro (2006) find a role for religious beliefs in explaining economic growth. These results are consistent with our findings in the sense that the religious beliefs of the BCL influenced individual investment decisions that enhanced economic performance.

The channel of economic development through human capital accumulation we find evidence for, is also emphasized by Galor and Moav (2006) and Boucekkine et al. (2007) and summarized by Galor (2010 and 2011). These papers build theories of early human capital accumulation as an engine for economic development. They argue that the process of capital accumulation gradually intensified the importance of skilled labor in the production process and generated an incentive for investment in human capital. It is also consistent with the emphasis on human capital accumulation as a driver for economic growth put forward by Goldin and Katz (1998; 2008). Van Bavel (2002) and Van Bavel and Van Zanden (2004) present evidence of high wages in the Netherlands from 1400 onwards. They argue that early industrialization, as a result of a shortage of arable land, increased the demand for human capital. This seems to be evidence in favor of the mechanisms developed by Galor and Moav (2006). Another channel of development is technological advancement. Dittmar (2011) 
shows that cities that adopted the printing press earlier grew faster. The key mechanism is that cities that adopted printing presses benefited from human capital spillovers and technological change (Baten and Van Zanden (2008) and Buringh and Van Zanden (2009) point at similar mechanisms). Our mechanism is consistent with this evidence, but shows that human capital development in Deventer started almost a century before the printing press arrived.

Finally, we provide a mechanism that seems important for explaining the history of the Netherlands in the period 1375 up to 1588. Our episodic mechanism is consistent with previous findings for this early period (e.g. Acemoglu et al., 2005; Van Bavel and Van Zanden, 2004; Blom and Lamberts, 1993; De Vries, 1984; De Vries and Van der Woude, 1997; Israel, 1995). Slechte (2010) provides an interesting historical record of the city of Deventer in which he describes the city as a major town for religion (the cradle of Modern Devotion), economic activity and trade in the fifteenth and sixteenth century. He also emphasizes the key role of Geert Groote in establishing Deventer as an important late medieval city.

The paper proceeds as follows. In the next section the mechanism of how the BCL has influenced education outcomes, economic development and societal change is explained along with historical evidence. Section 3 presents the empirical strategy and the most salient features of the data. In Section 4 three main sets of regression results are documented: the impact of the BCL on literacy and book production; the effects on economic development; and the relationship with the Dutch Revolt. Section 5 presents a number of robustness checks and discusses possible alternative explanations. Section 6 concludes.

\section{The Mechanism}

Our hypothesis is that the BCL, by fostering human capital formation, contributed to the early development of the Netherlands. The establishment of the BCL in Dutch cities promoted literacy among citizens by institutionalizing the educational system, by promoting an intense personal relationship with God through reading the Bible and other religious texts in vernacular, by stimulating a mixed life including both spiritual and economic selfmaintenance, and by the production of books as a form of manual labor to make a living in their houses. This way of promoting human capital formation contributed to early economic development and societal change in Dutch society. It contributed to economic development because cities in which the BCL established houses and educated citizens grew faster relative 
to cities in which the BCL was absent. The BCL contributed to societal change in the sense that it laid the foundation for Christian Humanism in Europe ultimately leading to the Revolt against the Habsburg rulers in 1572.

The mechanism that links the BCL to the early development of the Netherlands can be outlined in five steps related to (1) the context, (2) the approach, (3) the accumulation of human capital, (4) economic development and (5) societal change:

1. The BCL were established and diffused in a turbulent economic, social and institutional context of the late fourteenth and fifteenth century.

2. The BCL managed to accumulate human capital among citizens without inducing animosity from the Roman Catholic Church or political rulers.

3. The BCL built human capital by institutionalizing education, providing education for all and taking care of people.

4. Human capital accumulated through the BCL had an impact on the structure of economic activity.

5. The literate workforce put pressure on the Habsburg rulers leading to economic and religious resentment and eventually to the Revolt in 1572 .

Together, these five steps yield our main mechanism and predictions for empirical research.

\subsection{The Late Medieval Period in the Netherlands}

Before 1400 the Netherlands was a frontier country, which had many features of a newly reclaimed region. Farmers were allowed to occupy the area and received freedom and property rights. As a result, the Netherlands became to be characterized by medium-sized family farms worked by free peasant-owners. In contrast to most other parts of Europe, feudal structures were relatively lax and the position of the nobility was weak. Compared to surrounding regions, the occupation of the area was relatively late and cities were small.

The economic and political context of the late fourteenth and fifteenth century were a turbulent period in Europe. Population growth of the previous three centuries came to a stop. There were signs of overpopulation, food became expensive and some parts of Europe were famine-stricken. Political conflicts, precarious political balances and the plague worsened the situation (e.g., De Vries, 1976 and De Vries and Van der Woude, 1997). By the end of the fourteenth century the Netherlands could not be regarded as a united country. Citizens identified themselves with the cities and villages they lived in and not so much with the authority exercised by the several dynasties, such as the Duchy of Burgundy or Bavaria, or more local ones, such as the Duchy of Guelders, the counties of Brabant, Holland or the 
Bishopric of Utrecht (e.g., Blockmans, 1993). The northern provinces of the Netherlands were more or less independent and only mildly affected by the authority of the Holy Roman Empire. This changed in the sixteenth century when the Habsburg rulers became worried of the social unrest in the north, as we will discuss below in Section 2.5.

Important for understanding the head start of the economy are difficulties in arable farming, which forced people to find other sources of income. This led to industrialization of both urban and rural areas as early as the fifteenth century. The rapid development of urban industries (e.g., textile production, brewing and shipbuilding) and a rise in non-agricultural activities in the countryside (e.g., brick production) are well documented (e.g., Van Bavel and Van Zanden, 2004, for an overview). ${ }^{4}$ Together with the modest population decline relative to other European regions and high fertility rates in the fifteenth century, labor was cheap and abundant. This gave an additional boost to industrial production and increased urbanization rates. It also increased international trade with Dutch bricks being exported to England, Denmark and the Baltic. Also beer and textiles were exported to Flanders and Brabant.

This context of industrialization, trade and urbanization is important for the success of the BCL because it created a growing demand for human capital. Weak political institutions and the existing structure of property rights provided an incentive structure that also promoted human capital development. In this context, the supply of human capital was an important bottleneck for the development of Dutch society. The BCL, which was based on religious motives, eliminated this bottleneck by generating a new supply of human capital. The institutionalization of education and the 'education for all' philosophy stimulated an increase in human capital at a point in time at which Dutch society was in need of human capital. This 'lucky' coincidence of changes in demand and supply of human capital seems to be important for the impact of the BCL on the long-term economic and societal development of the Netherlands.

\subsection{The Foundation, Approach and Diffusion of the BCL}

Geert Groote (1340-1384) was the founder of the BCL, which has been put under the umbrella of Modern Devotion. Groote was a descendant of a rich family living in Deventer. He was not interested in running the family business and decided to devote his life to religion.

\footnotetext{
${ }^{4}$ See e.g., Kaptein (1998) for research on the Dutch textile industry from 1350 onwards, Unger (2001) for a history of brewing and Unger (1978) for an analysis of shipbuilding.
} 


\subsubsection{Foundation and Approach}

After he survived a serious disease, he established the Meester-Geerthuis in his native Deventer in 1374 as a semi-religious house in which religious communities found a home and in which care for the poor was provided (e.g., King, 1992 and Slechte, 2010). His subsequent missionary travels in the Netherlands focused on the importance of a personal spiritual life, which was achievable by all. He had preached in almost all big cities in the Netherlands by 1380 (see Hyma, 1950, p. 20). He also assisted in setting up houses and monasteries in other cities by providing financial means and appointing teachers and clergyman. Groote believed that individuals and communities should try to fulfill the apostolic command to poverty and chastity and to live virtuous lives in which they were allowed to make their own choices. The novelty of his approach was to serve the community and the freedom to choose. This view on religion and personal life was different from the view of the Roman Catholic Church, who viewed God as a rational governing principle with no influence of individuals on their life outcomes (see Post, 1968, p. 25).

Groote's motivation to establish the Meester-Geerthuis and his work as a deacon was stimulated by dissatisfaction with the moral decline in the Roman Catholic Church. ${ }^{5}$ The reform that the BCL pursued was to return to the customs among the early Christians. It is crucial to stress that this took place within the Roman Catholic Church. This is an important difference compared to the Reformation of 1517. Martin Luther stepped out of the Roman Catholic Church, which started Protestantism in Europe. ${ }^{6}$ Groote had no plans to leave the Church, but aimed at a reform from within. To achieve this, Groote translated parts of the Bible into Dutch, with additional explanatory notes, just before he passed away in 1384. In his writings he gave special emphasis to the use of vernacular so that all citizens could understand the messages for a virtuous life presented in the Bible. ${ }^{7}$ Another important element of his strategy is that he and Florens Radewijns travelled to Utrecht to get the BCL recognized by the bishop (Slechte, 2010). Utrecht was the religious center of the Netherlands,

\footnotetext{
${ }^{5}$ The motive force was at first primarily religious: "to return to a simple New Testament life, and to rest faith in a vernacular Bible accessible to all" (Laurie, 1896, p.143). This religious motive becomes also clear from King's description of the daily life in the first BCL house in Deventer (King, 1992).

${ }^{6}$ We discuss the crucial impact of the decision to remain within the Church below in Section 2.5.

${ }^{7}$ The focus on literacy is an important difference compared to the strategy adopted by the Cistercians. They also wanted to return to the old customs of early Christianity but promoted the importance of hard work and thrift (e.g., Barnebeck Andersen et al., 2011).
} 
with the bishop in charge of the religious community. At the time there were more people dissatisfied with the moral decline in the Church, but they were accused of heresy and often put to death. In 1398 bishop Frederik van Blankenheim agreed with the organization and religious motives of the BCL. This put the movement under ecclesiastical jurisdiction and took away the fear of becoming accused of heresy. Also the fact that Utrecht hosted four BCL-houses is consistent with the fact that the BCL was accepted within the Church (see Figure A.2.1). In addition, Groote advised his successor Florens Radewijns to set up monasteries next to houses. This also helped to reduce rumors of heresy to silence.

In the late fourteenth and fifteenth century more houses were established in Deventer, but also in other cities. Figure 2 shows the 35 cities with BCL-houses in the Netherlands. The 23 red dots are large cities with BCL-houses; the 12 blue dots are small cities. Large means 1,000 or more inhabitants in 1400 . There are 67 cities with these features in the Netherlands in 1400 . We use these 67 cities for our empirical analysis in Section 4 . The 44 white dots are the large cities without BCL-houses. Figure A.2.1 in the Appendix provides a map of all BCL-cities with the number of houses displayed in brackets.

The BCL had a unique character and organization, which differs from other forms of establishments and monasteries of that time in several ways. First of all, no wows were taken as used to be the case in other religious movements. Members enjoyed a mixed life balancing daily and religious activities. This mixed-life philosophy encouraged members to become influential in society (e.g., Erasmus) and to support the BCL-rationales on education and monastic reform beyond the range of influence of the Church (e.g., Martin Luther). Second, the form of manual work conducted in the BCL-houses was translating, copying and printing books. These books were sold to make a living. This was exceptional in the sense that all other known religious organizations and monasteries of that time engaged in agriculture as manual work. After the invention of the printing press around 1450 in Mainz, more brothers became engaged in printing and teaching activities. ${ }^{8}$ The organization of production in the houses became more specialized with some members becoming illustrators, others specializing in developing ornamental letters and so on. Finally and most importantly, the BCL developed literacy as a tool to achieve reform within the Church and society. The ideal to educate citizens increased the supply of educated people, who could read the Bible but also

\footnotetext{
${ }^{8}$ The diffusion of the printing press in Europe starts in Mainz around 1450. Johannes Gutenberg invented the printing press in Europe (e.g., Baten and Van Zanden, 2008 and Dittmar, 2011).
} 
other work that criticized the Church and societal habits. The lively civilian life in Dutch cities in the late medieval period with plays being performed on the market square seems to be a direct cause of the critical attitude towards central authority induced by literacy. In addition, citizens could also write contracts to trade. This impact of early literacy is what set the BCL apart from other religious movements of that time.

We view Geert Groote's new ideas as a reaction to the moral decline of the religious traditions of his time. ${ }^{9}$ The new ideas were not motivated by a desire to increase prosperity, literacy or revolt. Groote thought that religion was a personal matter. Therefore, one should be able to read the Bible, other religious texts and collections of sermons. This idea about religion led to a direct effect on literacy. It increased the demand for books because more people became literate. At the same time the supply went up, because of the unique form of manual labor in the BCL-houses. In Deventer demand became even higher because the Latin School grew and attracted students from all over Europe.

\subsubsection{Diffusion of Ideas}

The BCL formed the Modern Devotion movement around the city of Deventer. The movement was managed from Deventer. The first houses were set up in Deventer and in Zwolle. Houses from Deventer sent missionaries to Amersfoort (1395), Delft (1403) and Muenster. Houses in Zwolle were influential in the founding of houses in Albergen (1406), Hulsbergen (1407), 's-Hertogenbosch (1424), Doesburg (1426), Groningen (1430) and Harderwijck (1441). The people living in the house in Delft established one in Gouda (1445) and Utrecht (1474). The people of 's-Hertogenbosch founded a BCL-house in Nijmegen (1469). Most of the houses in Germany were founded by the missionaries from the Muenster and Cologne houses. And most of the rectors of the houses came from the houses in Deventer and Zwolle. Hence, it could be argued that the human capital was created in Deventer and Zwolle and used in the other BCL-houses across the country. Towards the end of the fifteenth century, the BCL allied themselves closely with the humanists, which further increased their societal impact (e.g., Laurie, 1896 and Hyma, 1951). ${ }^{10}$

\footnotetext{
${ }^{9}$ This seems similar to the transformation of Judaism at the beginning of the first millennium. Botticini and Eckstein (2007) argue that this transformation originated from a change in religious preferences. It was not motivated by economic incentives.

${ }^{10}$ In Deventer the BCL cooperated with the Windesheim Congregation and the Chapter Sion under the Augustinian Canons Regular. These were influential institutions in the local Roman Catholic Church.
} 
The influence of the BCL on Christian Humanism can be observed from the similarity of ideas and from networks of influential persons and schools. Christian Humanism started to gain influence between 1470 and 1490 in the cities of the north-eastern parts of the Netherlands (Deventer, Zwolle, Kampen and Groningen). ${ }^{11}$ It was a blend of Italian humanist science and Christian ideals, fostered by the tradition of the BCL. The ideas about personalizing religion from Thomas à Kempis' widely spread book The Imitation of Christ are fundamental for the Philosophia Christi of Rudolf Agricola and In Praise of Folly of Desiderius Erasmus, but also for the leading thinkers of the Reformation from 1517 onwards. Wessel Gansfort (1419-1489), one of the leading Modern Devotion representatives, worked in the north-eastern cities Zwolle, Deventer and Groningen. His work is known to have had a direct influence on Martin Luther's thinking. Agricola, who is considered to be the founding father of humanism in Northern Europe, was educated by the BCL and worked during most of his life in the Netherlands (e.g., Israel, 1995). The major individualistic reform movements that revolted against medieval scholasticism and the institutions that underpinned it, were laid by the BCL. It was spread by individuals, who were (despite the political environment) able to influence and teach citizens how to read and write (see Hyma, 1924, p. 16).

It also caught on in the universities. For example, the famous College de Montaigu in Paris became one of the leading theological faculties in the late fifteenth century. Among the students were Erasmus, John Calvin and Ignatius Loyola, the founder of the Jesuits. At the intellectual level the way the BCL viewed religion required a redefinition of God. God was no longer a rational governing principle. God was now a ruler, and religion would be more fervent and emotional. Luther, however, advocated that no mercy exists but from God, which was fundamental to his decision to leave the Roman Catholic Church in 1517.

The impact of the BCL on Christian Humanism and society can be seen from the relations between the leading thinkers of the BCL and Christian Humanism. Figure 3 presents a chronological network graph of the most important people educated by the BCL from 1400 to about 1550. The persons in the network are sorted according to their year of death. The

\footnotetext{
${ }^{11}$ Before 1490 Christian Humanism had an impact on the culture of the Netherlands through the urban and Latin schools, especially schools in the north-eastern Dutch cities. Geert Groote attended the Latin School in Deventer. Alexander Hegius (1439-1498), who was Agricola's main pupil, was the headmaster of the Latin School in Deventer from 1483 until 1493. This school, famous in the whole area including the German region of Westphalia, was the seed-bed of Dutch humanism. Erasmus (1466-1536) attended this school between 1475 and 1484. Around 1500 Deventer was the centre of humanist book production in Northern Europe with more Greek text editions than Paris (Schoeck, 1988).
} 
orange nodes indicate that the person was either affiliated with the BCL or received education in one of the BCL-schools. The size of each node shows the centrality of a person, i.e., how central a person and his neighbors are in a network. As can be observed from the picture, the BCL-affiliated people penetrated into the age of the Reformation and had connections with leading figures in the German, Swiss and British reform movements. Important intellectuals educated by the BCL include the humanists Desiderius Erasmus and Conradus Mutianus; printers such as Badius Ascensius (Jose Bade); prominent mystics and scholars such as Wessel Gansfort, Rudolph Agricola and Thomas à Kempis; and influential educators such as John Cele, Alexandre Hegius, Ludwig Dringenberg, John Standonck and Johann Sturm. More information on the data used to construct this network is provided in the Appendix.

\subsection{Building Human Capital}

The BCL built human capital in three ways: copying and printing books, supplying education to all and institutionalizing education to make it more effective and efficient.

\subsubsection{Copying and Printing Books}

Before the invention of the printing press, books were duplicated simply by copying from a master book, which in most cases was obtained through personal contacts. Copying books was an essential activity for the BCL and specifically mentioned in the preface of the constitution of the Deventer and Zwolle houses: "Our houses were founded with the intention that, in imitation of the Primitive Christian Church, priests and clerics might live there supported by their own labor, namely the copying of books, and by the return from certain estates" (cited in Hyma, 1968, p. 15). ${ }^{12}$ Agricultural work did not associate with the movement's cause and moreover book production was a major source of income for the BCL. Books copied by the BCL were known for the accuracy of texts and the quality of production (e.g., Haselden, 1939).

With the invention and diffusion of the printing press around 1450, copying manuscripts became inefficient and unprofitable. There were three implications of this development. First, brothers started to engage more heavily in teaching to compensate for the loss of income. Second, the BCL bought printing presses and supported other printers. Third, brothers divided the labor and became more specialized and efficient. Some focused on printing, others on illustrations or ornamental letters, etc. By 1490 about sixty printing establishments

\footnotetext{
${ }^{12}$ In the early 1440s the rector of the Doesburg BCL house turned manual work from book copying into agriculture. He was dismissed immediately (Post, 1961, p. 384).
} 
were controlled by the BCL (Haselden, 1939). In Brussels, the BCL operated the first and only printing press. All 37 incunabula editions (books published before 1500) from Brussels were printed by the BCL. Table 1 provides an overview of all books published before 1500 in the Netherlands. About fifty percent of all editions published in the Netherlands before 1500 were coming from the printing presses in Deventer (640 editions) and Zwolle (153 editions); 177 of these books were classics (Strand, 1968, p. 55). For comparison, the famous printing centre in Antwerp is responsible for 479 editions. By the year 1500 The Imitation of Christ by Thomas à Kempis, which is a major source book for the BCL, passed through 59 editions with 1,000 copies in each edition (Liebell, 1924). The Imitation of Christ was the second most read religious book after the Bible. The high density of printing presses in the Netherlands in the fifteenth century is confirmed by Dittmar (2011, Table 1), who shows that the share of cities adopting printing presses is among the highest in the Netherlands. In addition, the number of book editions relative to the size of the population was higher in the Netherlands than in other European countries, as shown in Table 2.

We view the production of books as an indicator of human capital as it seems likely that the supply of books is correlated with the demand for books. The production of books required a skilled staff that was able to read and write. Due to relatively high transportation costs in that period we expect that a substantial part of the total supply will be produced for the home market. For Deventer this is certainly the case because the students of the successful Latin school were important customers. In addition, the spread and selling of books among citizens could only be successful because it used vernacular. Both production and consumption demanded citizens who were able to read (and write).

\subsubsection{Education for All}

The BCL not only established houses but also paid considerable attention to public schools. Through this channel they were able to reach parts of society not directly influenced or controlled by to the Roman Catholic Church. This seems important for social and economic development outside the influence of the church. Schools in Deventer and Zwolle were among the best schools in transalpine Europe in the fifteenth century (e.g., Hyma, 1924; Post, 1968). ${ }^{13}$ John Cele (the rector of the BCL-school in Zwolle from 1375 to 1417) and Alexander Hegius (rector from 1483 until 1493) are well-known educators who supported the ideals of the BCL for monastic reform (see Post, 1968). The BCL supported schools and

\footnotetext{
${ }^{13}$ A large number of the letters of Groote were written to the rectors of Deventer, Zwolle and Kampen.
} 
intervened in the selection process of teachers and rectors.

The Deventer school reached 2,000 students under Hegius and the Zwolle school attracted about 1,200 students under the direction of John Cele. Given the population figures of the mid-fifteenth century, in both cities about 25 percent of the inhabitants were educated by the BCL. ${ }^{14}$ The BCL also established schools in various cities in the Netherlands and Germany such as Utrecht, Amersfoort, Nijmegen, Liege, Delft and Ghent. In some cases ('sHertogenbosch) the schools were established because the city magistrate requested the BCL to control the education in the city (e.g., Gem, 1907). In Utrecht the BCL had the monopoly on the supply of schools for pupils aged 12 and above. Similarly, in Amersfoort all secondary schooling was controlled by the BCL by 1555 (Henkel, 1968).

A major challenge was to spread literacy to more rural areas. By setting up hostels and dormitories for poor children, the BCL made education more accessible and encouraged poor children to attend schools. In Deventer, Zwolle, Amersfoort and 's-Hertogenbosch the hostels were large enough to accommodate up to two hundred pupils. Most of them attended the public school or the BCL-school in the city. Brothers generally played a role in the spiritual needs of these children but most of the time helped them with their studies. In all hostels there was a brother who was assigned the task to go over what students learned in class (Post, 1968, p. 394). At the same time BCL-houses were also established in smaller cities as Figure A.2.1 displays. Of the 35 cities with BCL-houses, 12 were cities with less than 1,000 inhabitants.

\subsubsection{Institutionalizing Education}

The eight-grade system, which is still what the current educational systems in most Western countries is based on, was originally invented by John Cele in Zwolle and later successfully adapted by the Deventer BCL-school. This innovation, that significantly improved teaching

\footnotetext{
${ }^{14}$ To illustrate the significance of this number in terms of learning and education we can compare it to contemporary Boston and London, two of the top university cities according to Global University City Index (see http://www.rmit.com.au/browse;ID=q31220b3wzs5 for details). In 2009 there were about 135,000 students enrolled in tertiary education programs in Boston which corresponds to 21 percent of Boston city population. The figures are for students who are enrolled in a university in Boston city. If we consider all universities in Boston metropolitan area the number is as low as 6 percent (see the U.S. Department of Education National Center for Education Statistics at http://nces.ed.gov/globallocator/). For London with a tertiary student population of about 400,000 this figure is about 6 percent. According to the Higher Education Statistical Agency there are 265,111 university students in London in 2005. Including all other colleges and tertiary schools, this is about 400,000 (http://www.londonhigher.ac.uk/294.html for details). This number is about 12 percent for Amsterdam (about 89,000 students).
} 
standards, had a great impact on institutionalizing education.

By dividing secondary school education into eight classes, the curriculum became less demanding for children. The first grades were based on more practical teaching (i.e., knowledge that everybody needs) and advanced courses were taught later on. The usual teaching-day of about ten hours was reduced by almost fifty percent. Personal notes of pupils were collected in a book for further practice and visual aids, such as maps, were incorporated in teaching (Henkel, 1968). The system was organized in such a way that students in the eighth grade, assisted students in lower grades, sometimes even in the form of tutoring and the organization of exams. The most important innovation of eight-grade division was the inclusion of trivium (grammar, logic and rhetoric) and quadrivium (arithmetic, geometry, music and astronomy) in the curriculum. This system corresponds to the first two grades observed in medieval universities. Under the auspices of Alexander Hegius (in Deventer), advanced courses even included Latin, Greek and Hebrew. These attempts were among the first to introduce humanistic thoughts into education.

The BCL was instrumental in transferring this new organizational innovation in education to other cities in the Netherlands and the western and south-western parts of Germany. The system reached a degree of maturity under Hegius in Deventer and gradually diffused from Deventer to other cities. Being educated in the Deventer school, Louis Dringenberg used similar principles to set up the first school in a humanistic fashion in Schlettstadt, Germany in 1441 (Hyma, 1924, p.16). In similar way, John Murmelius applied the new system to schools in Muenster.

In Amersfoort the system was amended to have nine grades. Liege also had a nine-grade system. Johann Sturm copied the organization in Liege to the school in Strasbourg around 1538. He specifically credited the BCL and the school in Liege as the source of his educational reform. From Strasbourg, the eight-grade system penetrated into Germany. John Calvin, who was an assistant of Sturm in Strasbourg from 1539 to 1541, carried the system to the school he established in Geneva in 1559. Calvin organized the school in seven grades with more emphasis on biblical texts. He reduced the share of classical literature.

When Jesuits were called to Rome in 1584 to suggest improvement in the organization and administration of education, they suggested a system that resembled the BCL school system. The final form of this plan (published in 1599) resulted in the foundation of schools in which education was organized according to an eight-grade system. Pijper (1914) argues that 
English puritans carried this system to America; McCarrel (1934) argues that the BCL influenced the development of training schools in the United States. ${ }^{15}$ Germany, Belgium and Switzerland followed the earlier innovations in education with a lag of about a century.

It is interesting to observe that the reflection of this on literacy rates was persistent until the mid-eighteenth century (e.g., Allen, 2003). In Figure 4a we can see this by plotting literacy rates from 1600 to 1775 . The data is gathered from the marriage records after 1580 in the Amsterdam Archives (Hart, 1976 and Kuijpers, 1997). ${ }^{16}$ The percentage of grooms that signed the marriage record is considered as a proxy for literacy. As can be seen from the graph, literacy rates in the Netherlands were about two times those of Germany and this gap closed only in the mid-eighteenth century. If we look at literacy rates in different parts of Germany and the Netherlands the picture is even clearer. Figure $4 \mathrm{~b}$ compares literacy in three hanseatic trade cities in the eastern part of the Netherlands (Deventer, Kampen and Groningen) with those in three important German hanseatic trade cities (Bremen, Lübeck and Hamburg). It seems that the cities that are closer to the Dutch border were more literate than the ones located in the eastern part of Germany. West German towns had comparable literacy rates relative to their Dutch neighbors starting from the eighteenth century. There seems to be a literacy gap ranging from 70 percent in 1600 to 15 percent in 1800 between the Netherlands and West Germany. Considering that the three powerful hanseatic cities are important cities for trade we expect the literacy on average rates to be lower in other parts of Germany. ${ }^{17}$

\subsection{Economic Development and Urbanization}

The increased supply of human capital was met by the emergence of modern structures in the fifteenth century. There was a sharp increase in urbanization rates from about 15 percent in 1300 to 45 percent in 1500 (Van Bavel and Van Zanden, 2004). This rapid rise to the highest level of urbanization in Europe in 1500 has been attributed to the difficulties with rising water tables and subsiding peat soils, which made arable agriculture expensive, and with the

\footnotetext{
${ }^{15}$ See Congleton (2008) for a comprehensive view on the link between the early development of the Netherlands and America's early constitutional development.

${ }^{16}$ From the records of about a million marriages from 1580 onwards in Amsterdam it is possible to see whether the groom and bride signed or put a mark indicating approval of the marriage. There is also indication of where (city of origin) the groom or bride is coming from. See Appendix Section A.2.1 for more information.

${ }^{17}$ Allen (2003) presents data, which suggest that literacy rates in the Netherlands are about 40 percent in 1600. In France, Germany and the United Kingdom literacy rates were much lower in 1600 (between 12 and 19 percent).
} 
mild impact of the plague in the Netherlands (e.g., Van Bavel, 2002). In contrast to for example England the population of the Netherlands grew in the fifteenth century. It is wellknown that urbanization played a central role in the emergence of modern economic growth (e.g., Braudel, 1979). Bairoch (1988) argues that urban life generated social interactions that improved information flows and increased innovation. DeLong and Shleifer (1993) and Acemoglu et al. (2005) also observe that cities produced the economic environment of Europe. In Section 4 we link differences in the growth of cities to the presence of the BCL.

Urbanization changed the nature of production, as we discussed above. ${ }^{18}$ The Netherlands experienced an early transition to industrialization of production away from agricultural production. This process is enhanced by human capital accumulation because it allows for trade. International trade in the northern cities was earlier on organized by the Hanseatic League. The BCL was important in cities such as Deventer, Kampen, Zwolle, Groningen and Zutphen, which were also important cities for hanseatic trade. However, the diffusion of the BCL in the Netherlands differs from the hanseatic trade routes. The BCL also spread to cities in Brabant and in Holland and the spread of the BCL cannot be linked to the waterways used by the Hanseatic League. The primary reason was that the city of Deventer was not a key player in the Hanseatic League. Its trade took place with the cities in Holland and Zeeland and the South-Eastern hinterland until Cologne. This network was already established before the Hanseatic League became important in the Netherlands. Deventer was also not very interested in the decisions made by the governors of the League. Representatives of the city were not often present at the annual meetings and the city did not take part in naval wars (e.g., Slechte, 2010). It is therefore not a surprise that we find no correlation between hanseatic trade and the BCL in a probit model that controls for geographical characteristics. In Section 5 we address this issue more formally.

Finally, sea-going trade has been crucial for the rise of Europe (Acemoglu et al., 2005). However, the time period we study in this paper came before the period in which sea-going trade became important. Table 3 shows the ten largest Dutch cities in 1400, 1560 and 1800. Of the ten largest cities in 1400, five have a sea border. The largest two cities do not. Amsterdam is not in the list of largest cities, nor is Rotterdam. In 1560, Amsterdam is the largest city. Next to Amsterdam, Haarlem, Delft, Leiden and Dordrecht have a direct sea

\footnotetext{
${ }^{18}$ Most cities in the Netherlands were granted city rights in the early Middle Ages, which is long before the start of the BCL. Deventer received city rights in 956, Groningen in 1050 and Utrecht in 1127. Before 1300 more that 70 percent of all Dutch cities had city rights.
} 
connection. Only in 1800 the largest cities (Amsterdam and Rotterdam) are the ones with a sea connection. The government capital of The Hague is third in terms of population. It seems to be the case that there is a watershed in the development of the Netherlands after 1560. This has been attributed to the commercial interest of international trade that shaped conflicts between the Habsburg rulers and Dutch merchants (e.g., Israel, 1995). ${ }^{19}$ The developments in the Netherlands in the fifteenth century seem different from the conflicts around the creation of the Dutch West India Company in the early seventeenth century. We will show in Section 4 that there is an effect of the BCL on city growth in the period 14001560 , but not in the later period up to 1795 .

Industrialization, trade and urbanization require human capital. Various recent studies provide evidence for the impact of human capital formation on economic change in fifteenth and sixteenth century Europe (e.g., Baten and Van Zanden, 2008), but are silent about the sources of the supply of human capital. The founding and diffusion of the BCL in the Netherlands might explain how the supply of human capital increased.

\subsection{The BCL and Societal Change}

The Reformation had its symbolic start in 1517 when Martin Luther posted his theses on the All Saint's Church in Wittenberg. Luther was educated at the Latin school in Magdeburg, which was led by the BCL. The main ideas of Christian Humanism constitute the roots of the Reformation. For instance, Erasmus distinguished 'false religion' from ‘true Christianity'. He stimulated individuals to organize their own personal life like the life of Christ and to stay away from false devotion, such as statues, veneration, pilgrimage, fasting and ceremonial rituals. Erasmus criticized the behavior of the clergy and the corruption and immorality in monastic institutions in the same way as Groote did before.

The Reformation in the Netherlands developed in a different way than the Reformation in Germany or other parts of Europe. This delay can be directly linked to the BCL. For many decades the Reformation in the Netherlands remained an uncompleted Reformation, and this seems a key factor for the Dutch Revolt against the Spanish rulers. From 1490 onwards Christian Humanism quickly diffused in the Netherlands, more than in any other country in Northern Europe. ${ }^{20}$ It was more deeply rooted and diffused in the Netherlands than in other

\footnotetext{
${ }^{19}$ Van der Wee (1971), Van Zanden (1993) and De Vries and Van de Woude (1997) reach similar conclusions.

${ }^{20}$ Christian Humanism conquered Latin Schools, found many followers in city administrations and had a large impact on education, culture and religious consciousness (Israel, 1995).
} 
European countries. However, the Habsburg rulers (Charles V and Philip II) sent more troops to control the political and social situation in the Netherlands. They were more afraid of Christian Humanism in the northern parts of the Netherlands because of its early start and wide-scale support due to the high levels of literacy among citizens. To fight the reformatory movements, the Habsburg rulers used severe repression against all deviant religious practices. This is known as the inquisition. Another factor that is likely to have contributed to the different development of the Reformation in the Netherlands is the opinion of Desiderius Erasmus. He wanted to bring change from within the Roman Catholic Church and did not object to the institution of the Church or faith, again a similar position as taken by Geert Groote a century before. Erasmus was also afraid that the reaction to Luther's protest against the Roman Catholic Church would backfire on the whole movement of Christian Humanism.

The strong repression by the Habsburg rulers created a situation which has been described as a 'mental civil war' with strong alienation of substantial parts of the population from the state and the traditional church (Israel, 1995). In 1566 a covenant of members of the lesser nobility came together and submitted a petition to the Regent Margaret of Parma. The objective was to obtain a moderation of the placards against heresy in the Netherlands. This petition played a crucial role in the events leading up to the Dutch Revolt. In the next months the Netherlands became the scene of the Beeldenstorm, a riotous iconoclastic movement by Calvinists, who stormed churches and other religious buildings to desecrate and destroy church art and all kinds of decorative fittings over most of the country. The movement started in the southern part of the Netherlands and seemed to have a spontaneous character. However, after spreading to the northern provinces, the movement started to have a systematic and organized character by the inference and coordination of nobility and influential citizens (Israel, 1995).

A remarkable difference between the north and south was that there was no Catholic reaction against the iconoclastic violence in the north. Israel (1995) suggests that this difference indicates a lack of support for the traditional Roman Catholic Church and the Habsburg rulers in the northern provinces. Slechte (2010) confirms this for the city of Deventer. In the Latin School teachers and students sympathized with the ideas of Martin Luther. The arguments spread to the BCL-houses and monasteries, which led to resignation of many brothers from the movement. Philip II reacted to the situation in the north by sending an army of 10,000 troops, led by General Alba, to suppress the rebellion. Alba took harsh measures and rapidly established a special court with a staff of 170-200 people (Raad van Beroerten or Council of Troubles) to judge anyone who opposed the King. No one, not even high nobility who had 
been pleading for less harsh measures, was safe. Israel (1995) notes that it is remarkable that this council, with an exception of the southern cities of Doornik, Antwerp, Valenciennes and Ieper, found more evidence of organized opposition and heresy in the northern part of the Netherlands, indicated by relatively more convictions in the northern cities. When we correlate the presence of a Council of Troubles in a city with the presence of the BCL, we find a strong and significant correlation coefficient of $0.43(n=35)$. Also the correlation with the number of convictions by a Council of Troubles and the presence of the BCL is statistically significant $(0.39, n=35)$. This suggests a relationship between the growing fiscal and religious resentment and the early activities of the BCL, which made people more skilled, literate and critical towards the Habsburg rulers' measures. In Appendix A.2.4 we list the number of cities used to obtain these suggestive correlation coefficients. The fiscal resentment, based on a set of new fiscal measures including an additional 10 percent tax on all trade transactions (the so-called Tiende Penning), is generally seen as a trigger for the Revolt. It is however not considered as the genuine cause, which was more profound and related to different views on religion and state (e.g., Israel, 1995, Slechte, 2010 and Woltjer, 2011).

The large number of executions led the court to be nicknamed the "Blood Court", and Alba to be called the "Iron Duke". Rather than pacifying the Netherlands, these measures helped to fuel the unrest. In addition, the number of refugees from nobility and influential citizens was much higher in the north than in the south. The threat of losing power and wealth might have been an argument for these groups to start revolting. The Dutch Revolt started on 1 April 1572 by a group of 600 rebels ('Gueux') who took the small coastal city of Brielle. In the next months the Revolt spread especially in the northern areas of the Netherlands. After many years of war against the Spanish armies the seven Northern provinces became independent in 1588 which marks the start of the Dutch Republic. Figure 5 shows the revolting cities in the Netherlands. The numbers attached to the dots indicate the time measured in days that elapsed after Brielle was taken over by the rebels. These dates are drawn from historical records (e.g., De Graaf, 2004; Parker, 1977). A list of cities and Revolt dates is presented in the Appendix (Section A.2.4).

\section{Data and Empirical Strategy}

The aim of the empirical analysis is to formally investigate the impact of the BCL on economic and societal outcomes. Our main variables are: the locations of the BCL, book 
production, literacy, city growth and the likelihood of joining the Dutch Revolt. We use a number of data sources for these variables. In this section we present the most salient details. Detailed variable definitions and data sources as well as an elaborate description of our data treatment can be found in the Appendix.

Our main independent variable is a dummy for the presence of the BCL in a city. Information on the presence of the BCL is collected from Hyma (1924; 1950; 1951 and 1958), Post (1968), Fuller (1995) and Van Engen (2008). Figure A.2.1 shows a map of the Netherlands in which we present the cities with a BCL-house. For most cities we also have information about the number of BCL-houses. There are 15 cities with more than one BCL-house. The number of houses is presented in brackets if it exceeds one. We therefore also present analyses with the number of houses instead of dummy variables for presence of the BCL. The information on the number of houses is less reliable than the presence of BCL-activity because it is not always clear whether all houses have been registered (e.g., Post, 1968).

As dependent variables we use two indicators of human capital: book production and literacy rates. The data on book production for the period 1470-1500 are from the British Library Incunabula Catalogue. Data on literacy in 1600 come from the Amsterdam Archives and Hart (1976). Male literacy is defined as the share of grooms that signed by writing their names for their marriage in Amsterdam instead of stamped for it by finger print. The place of birth of grooms provides information about literacy in other cities (see the Appendix for more details on these data). The literacy rates we obtain in this way are available for 33 cities. It should be noted that the literacy rates are based on samples of migrants to Amsterdam, which might induce measurement error, for instance due to the distance to Amsterdam. In the analyses in which we use this literacy variable we control for distance to Amsterdam. In addition, the rate of literacy in Amsterdam in 1600 was close to the average in our data; 70.1 percent for Amsterdam, 65.5 percent on average in the Netherlands (Kuijpers, 1997).

As our third dependent variable we look at city growth. We use data on city growth between 1400 and 1560 for a sample of 67 cities with 1,000 and more inhabitants in 1400. Data on smaller cities (around 500 inhabitants) are unreliable because for most of these cities a number of exactly 500 is reported (e.g., Lourens and Lucassen, 1995).

The fourth dependent variable that we are interested in is the Dutch Revolt. We investigate whether cities in which BCL was present were more likely to join the Dutch Revolt and started earlier with the Revolt. The dates of the start of the Revolt for 38 cities are known 
from historical records (e.g., De Graaf, 2004; Parker, 1977). Figure 5 presents a map with the lags in days after the rebels took Brielle.

Table 4 shows descriptive statistics of our main variables for cities with and without a BCLhouse. A first impression based on these statistics is that the presence of the BCL is associated with a higher literacy rate in 1600, more book production, higher growth of the population until 1560 and a stronger involvement in the Revolt.

For the empirical analysis we follow a two-step approach. As a first step we regress a specific outcome $(Y)$ for city $i$ on the presence of the BCL $(B C L)$ and include a set of controls $(X)$ :

$$
Y_{i}=\alpha_{0}+\alpha_{1} B C L+\alpha_{2} X_{i}+\varepsilon_{i}
$$

Estimation of this equation provides us with a coefficient for the association between the BCL and the outcome of interest. A concern with this estimation is that the location of BCLschools might not be random. For instance, the presence of the BCL might depend on the local demand for education, the wealth of a certain area or the city growth in the previous period. If such factors are correlated with the outcome variable, but unobserved by the researcher, the estimated association in equation (1) does not yield the causal effect of the BCL on the outcome variable.

To further investigate whether the associations between the BCL and outcomes can be interpreted as a causal relationship, we apply an instrumental variable approach, in line with some recent studies on the impact of historical events (e.g., Becker and Woessmann, 2009; Dittmar, 2011). BCL was founded in Deventer. In the early period human capital was developed in Deventer and Zwolle (a city close to Deventer where Florens Radewijns was an active partner of Geert Groote) and diffused to other BCL-houses across the country. We use the distance to Deventer $(D D)$ as an instrument for the presence of BCL-activity. This yields the following first-stage equation:

$$
B C L_{i}=\beta_{0}+\beta_{1} D D_{i}+\beta_{2} X_{i}+u_{i}
$$

The identifying assumption is that distance to Deventer is not correlated with the unobserved factors in equation (1). The history of the foundation of the BCL suggests that the location of Deventer as the base location can be considered as random. Geert Groote was inspired to found the BCL after he overcame a serious illness. His motivation seemed purely religious and unrelated to the economic and social outcomes we investigate in this study. Distance to 
Deventer is expected to be important for the diffusion of BCL because in those days even small distances meant a lot of travel time. Hence, distance would have played a role in the choice of the locations of new BCL-houses. In addition, the BCL formed the Modern Devotion movement which was managed from Deventer. For the maintenance and growth of the new movement in a critical environment, the distance to the intellectual sources in Deventer (and Zwolle) will have been important. The Deventer BCL community acted as the center of the movement. As early as the end of fourteenth century missionaries were sent from Deventer to Amersfoort, Münster and Delft to form BCL-houses in the spirit of the houses in Deventer (Hyma, 1924). The houses in Deventer were like schools that produced rectors, priests and procurators for other houses in the Netherlands (Post, 1968). In this way the BCL-houses in Deventer interacted with other houses in the country. As such, we expect that distance to Deventer will be related to the diffusion of the BCL. Although the source of the BCL is exogenous, the choice of the new locations was not random. Cities with a higher population size in 1400 were more likely to be the location of new BCL-houses. It might be expected that conditional on distance the BCL had a preference for larger communities in which more people could be reached. To take this non-randomness into account, we control for population size in 1400 in all our models. The variation that we exploit in the IVestimation is that cities that are similar in population size in 1400 will differ in the probability of having a BCL-house due to the distance to Deventer. We further assess the identifying assumption by investigating the association between distance to Deventer and the educational infrastructure in the Netherlands before 1400, a number of placebo city distances and city growth in the century before the founding of the BCL.

\section{Estimation Results}

This section presents three sets of results of how the BCL affected human capital accumulation and economic development and how it fostered societal change.

\subsection{The Effect of the BCL on Human Capital}

In addressing the effects of the BCL on human capital, we present two pieces of evidence. First, Tables 5 and 6 present estimates in which we explain differences in book production across cities in the period 1470-1500 by the presence of local BCL-houses and by the number of BCL-houses. Second, Table 7 reports results of an analysis in which we explain differences in literacy rates around 1600 by the presence of the BCL in cities and by the number of BCL-houses. It is likely that these two indicators of human capital (book 
production and literacy) will be correlated, which could lead to overestimations of the effect of the BCL in the separate analysis on book production and literacy. However, for our analysis this is not really an issue as we use book production and literacy to proxy early human capital accumulation in the Netherlands.

The first column in Table 5 reports the OLS estimate of the BCL dummy variable on the production of books in 66 cities in the Netherlands. The production of books is proxied by the share of book editions. We use data on book production in the period 1470-1500 because this is the earliest possible period for which data are available, since the invention of the printing press around 1450 in Mainz (e.g., Dittmar, 2011). We use the share of book editions, because the number of books per edition is not known. We have left the city of Deventer out of the analysis because a huge share of the total book production in the Netherlands was done in Deventer in the late fifteenth century (see Table 1) and Deventer is the source from which the BCL originated. The estimated coefficient suggests that the presence of the BCL increases the share of book production by 2.3 percentage points. Controlling for population size in 1400 and geographical factors (dummy variables for location at the sea, a major river or a Roman trading route) does not substantially change the effect, as the estimates in columns (2) and (3) suggest. Because Deventer produced so many books in the Netherlands, leaving out Deventer reduces the size of the estimated coefficients. We weigh the observations by city population in 1400 because of the likelihood of measurement error in smaller cities with only little or no book production. As Table 1 has shown, the production is rather skewed with a substantial part of the books produced in a few cities, such as Zwolle, Gouda, Utrecht and Leiden. In column (4) we present the estimates of including the number of BCL-houses instead of a dummy for presence. The estimate is comparable to the one in column (3).

In Table 6 we report the estimates of the instrumental variable regression. In the results displayed in columns (1)-(6) we instrument the BCL by distance to Deventer to show that it is likely that the BCL has a positive effect on book production. The first-stage results reported in columns (1), (3) and (5) reveal negative and significant correlations between distance to Deventer and the BCL. The F-tests are sufficiently large to ensure the analysis does not suffer from weak instruments. The 2SLS estimates in columns (2), (4) and (6) show statistically significant positive effects of the BCL on the share of printed book production across the 66 cities in our sample. The standard errors in the 2SLS approach are higher, which leads to a drop of statistical significance to the 10 percent level. The point estimates remain similar. These estimates indicate that the presence of the BCL increased book production with 2 to 3 
percentage points. The final two columns report estimates for the number of BCL-houses, which also show a positive effect of BCL on book production. In sum, these estimates suggest that the BCL has supported human capital development.

In Table 7 we show the results of a regression analysis in which we estimate the effects of BCL on male literacy in 1600 . Our sample consists of 33 cities for which literacy data is available as early as 1600 . Male literacy is defined as the share of grooms that hand-signed for their marriage in Amsterdam instead of stamped for it by finger print. Since we know the place of birth of each of the grooms, this provides information about literacy in other cities. The marriage records we use as the dependent variable are from the period 1600-1625. The coefficient in column (1) suggests that literacy is about 6 percentage points higher in BCLcities. In the estimates reported in columns (2)-(3) we add (log) population in 1400 and distance to Amsterdam. The reason for including distance to Amsterdam is that travelling to Amsterdam around that time may have taken a while, which makes it more likely that the grooms from outside Amsterdam are from neighboring cities or at least cities relatively nearby. The estimated coefficients for the BCL remain similar and distance to Amsterdam does not have a significant effect on literacy outcomes. Because of the small number of observations, we do not add more covariates to the regression equation. Another concern with these data could be that males from cities in which the BCL is present are more successful because they are more likely to be literate. We therefore investigated whether marriage rates in BCL cities are higher than in other cities in 1795, the year for which the first marriage data for the Netherlands are available. This is not the case. Finally, we also have information about female literacy. When we pool men and women we find similar estimates, with the exception of the specification in column (2) which turns insignificant.

The instrumental variable analysis is reported in columns (4)-(9) of Table 7. The first-stage estimates show that distance to Deventer is associated with the probability of a BCL-house in a city. Each 10 kilometers distance to Deventer is associated with a 6 percentage points reduction in the probability of a BCL-house in a city. The F-tests for the first-stage regressions indicate that the instrument used in the model without controls (column (4)) might not be strong enough for a causal interpretation of the second-stage estimate. After including controls possibly weak instrument concerns do no longer apply. The second-stage results in column (5), (7) and (9) only use the variation in the presence of a BCL-house or in the number of BCL-houses that is associated with the distance to Deventer. The IV-estimates confirm the positive effect of one or more BCL-houses on the literacy rate of a city. An 
analysis for the pooled sample of males and females shows similar and statically significant results. The estimation results are very similar in models in which the observations are weighted by the number of grooms from each city. This procedure might reduce bias by measurement error.

The estimates in Table 7 also suggest that the OLS-estimates in the left columns are negatively biased and correlated with unobserved factors that reduce literacy in a city. Becker and Woessmann (2009) also find substantially higher 2SLS estimates in their analysis of the effect of Protestantism on literacy. The negative selection bias in their analysis seems to be related to the diffusion pattern of Protestantism towards poor areas with a more prevalent opposition to the Catholic establishment. Although the BCL did not vociferate against the Catholic establishment, BCL-houses might have diffused in a similar way. It might have been easier and more attractive to set up a BCL-house in cities were the Catholic influence was less strong. Due to the specific period of our investigation it is difficult to empirically document this negative selection bias. The scarce data that are available about the developments before the BCL (see Sections 5.1 and 5.2) show that the diffusion of BCLhouses was not associated with the presence of existing schools or with city growth before 1400. The strong increase of the estimated effect might also be explained by the limitations of our literacy data from 1600. The data are based on marriage records of individuals who migrated towards Amsterdam from 33 cities. If migration towards Amsterdam was somehow linked to literacy and to BCL, hence, if literate individuals from BCL-cities were more likely to migrate to Amsterdam, we would overestimate the effect of BCL on literacy. Due to the obvious limitations of the historical literacy data, we believe that our estimation results should not be interpreted as clean evidence regarding the effect and the size of the effect of the BCL on human capital. However, the results should be taken with caution and only be interpreted as an indication for the positive relationship between the BCL and literacy. Overall, these two sets of estimates for book production and literacy rates are consistent with the part of our mechanism that suggests that the BCL facilitated human capital accumulation.

\subsection{The Effect of the BCL on City Growth}

Table 8 presents the effects of the BCL on economic development. In particular, we focus on city growth between 1400 and 1560 for our sample of 67 cities. In this period, the economy of the Netherlands seems to have entered a transition phase as described by Van Bavel and Van Zanden (2004) in which a higher level of development is absorbed by higher population growth. Galor and Weil (1999) have referred to such a transition as a Post-Malthusian regime 
in which technological change and human capital translate into population growth.

The regression analysis reveals a strong positive effect of the BCL on city growth. The OLS estimates in Table 8 suggest that the presence of the BCL increases city growth by approximately 35 percentage points, with the exact impact depending on the specification. All specifications control for initial size. We add the same geographical controls as above. Cities along the sea coast also seem to grow faster. Whether or not cities are located next to a main river or whether they are closer to Roman trading routes does not seem to matter for their growth in this period. When we use the number of BCL-houses we also find a positive effect of BCL on city growth (see column (3)). A concern with these estimates is that they might be driven by a small number of fast growing or deteriorating cities. Therefore, we reestimated the full model for a sample that excluded cities that grew or shrank more than 100 percent in the period 1400-1560. The estimates in columns (4) and (5) for this sample of 61 cities are very similar to the previous estimates.

To further establish a causal interpretation of the impact of the BCL on economic development we instrument the BCL with distance to Deventer. Table 9 reports the estimation results. The first-stage results in the odd numbered columns along with the F-test for the validity of the instrument make us confident that the analysis is sensible. The 2SLS results in the even numbered columns confirm a positive, and statistically significant, effect of BCL on city growth. The estimates in columns (7)-(10) show that these results are not driven by a small number of very fast growing or shrinking cities.

Taken together the estimated coefficients support a causal interpretation of the effect of the BCL on city growth in the Netherlands in the period 1400-1560. These estimates are consistent with the observation that the Netherlands experienced a wave of urbanization before other European countries did (e.g., Bairoch, 1988), which has given them a head start. What our estimates add to these observations is an economic interpretation along with a mechanism: the presence of the BCL offers an explanation for why economic development was ahead of others.

\subsection{The Effect of the BCL on the Dutch Revolt}

The third set of results links the BCL to societal change. In particular to the Dutch Revolt, which started on 1 April 1572 when General Alba was beaten by a group of 600 rebels who took Brielle. The rebels raised the Prince of Orange's flag above the city. Immediately after the seizure of Brielle other cities started to revolt against the Spanish occupiers and the Prince 
of Orange entered the country from the east at Nijmegen. The Dutch Revolt diffused relatively quickly across the Netherlands, as Table A.2.4 in the Appendix and Figure 5 show.

From historical records (De Graaf, 2004; Parker, 1977) we obtain which cities took part in the Revolt and at what dates they joined the rebellion. This information is available for 38 cities in our sample of 67 cities. Since the Dutch Revolt diffused across the whole of the Netherlands, all cities were influenced (Parker, 1977). So it is unlikely that for cities for which no official revolting date is known, the Revolt was not happening. We have constructed revolt dates for the remaining 29 cities for which we do not have the historical date of the Revolt by using the average value (of days after the revolt in Brielle) of the region. This reconstruction is based on the assumption that the Revolt spread gradually across the country. This assumption might not be entirely valid since it is known that the Revolt sometimes jumped from one city to another, skipping cities in between. For instance, Amsterdam only joined the Revolt after six years (in 1578). However, in Zeeland and most parts of North Holland the revolt spread through the movements of the rebel armies from city to city (Van Nierop, 1999).

We have performed two sets of analyses. First, we investigated whether BCL-cities were more likely to join the Revolt. The dependent variable in this analysis is based on the historical records mentioned above. Second, we investigated whether the Revolt started earlier in BCL-cities. The dependent variable in this analysis is partly based on a reconstruction of the revolt dates. The revolt dates that we have reconstructed are treated as constrained values in the regression. Because of the reconstruction of the values we should be more cautious in interpreting these results. The regression analysis presented in Table 10 shows that the BCL has a positive association with the Revolt. The presence of the BCL increases the probability of a city joining the Revolt with about 25 percentage points. The 2SLS-estimates in columns (3)-(6) confirm these findings and suggest that the BCL-effect might be stronger. Our main finding is that BCL-cities were more likely to join the Revolt.

The final two columns in the right panel of Table 10 show the estimates for the timing of the Revolt in the cities of our sample. The dependent variable is the number of days it took before the Revolt started in a city, after 1 April 1572. The estimates from the (two-sided) censored regression model show that the Revolt started earlier in BCL-cities. ${ }^{21}$ The estimated

\footnotetext{
${ }^{21}$ For the left-side censoring we used 0 days and for the right-side censoring we used the maximum or the average days of the revolt across all regions.
} 
effects suggest that the Revolt occurred about a month earlier in cities with BCL-presence. We interpret these latter results with caution, because the means presented in Table 4 do not reveal a statistically significant difference in the number of days it took before the Revolt took place in the different samples of cities.

Next to the direct effect of the BCL on the Dutch Revolt, there could be an effect through literacy. Christian Humanism particularly developed in cities with BCL-activity and these cities were on average more literate. Cities with more citizens who are literate were more likely to participate in the Revolt because they were constrained and suppressed under the Spanish rulers. We were able to match the data about literacy and the Dutch Revolt for 19 cities. Figure 6 plots the literacy rates of these cities against the timing of the Revolt. The negative slope in the figure suggests that cities with a higher literacy joined the Revolt earlier. $^{22}$ Overall, these estimates show that BCL can be linked to the start of a major social change in the Netherlands.

\section{Robustness}

This section reports a number of robustness checks and examines a number of possible alternative explanations.

\subsection{Educational Developments before the BCL}

The BCL could have built its educational efforts on the presence of existing schools. Table 11 reports estimates, for our sample of 67 cities, of the presence of schools before 1400 on the probability of the presence of the BCL in that city. We have collected the data on the presence of schools before 1400 from Post (1954). We have estimated three probit models. In column (1) of Table 11 we find a statistically insignificant coefficient for the presence of pre1400 schools on the BCL. Adding a set of covariates to the specifications reported in the next two columns reduces the point estimates towards zero. These estimates suggest that the BCL is independent of previous educational efforts in the Netherlands. Similar regressions of distance to Deventer on the presence of schools before 1400 yield statistically insignificant results.

\subsection{City Growth in the Netherlands before 1400}

Another possibility is that cities grew already before 1400 and that the BCL was especially

\footnotetext{
${ }^{22}$ We did not apply a two-sample two-stage least squares estimation (Angrist and Krueger, 1992) because of the small sample of cities for which we can match literacy and the Dutch Revolt. This analysis would imply an out of sample prediction for 50 observations for which the Revolt date is known but the literacy rate is missing.
} 
present in growing cities. Information about populations is only available for 15 Dutch cities before 1400. Bairoch (1988) reports population figures for 1300 and 1400 for Amsterdam, Delft, Deventer, Dordrecht, Groningen, Kampen, Leiden, Maastricht, Middelburg, Nijmegen, 's-Gravenhage, 's-Hertogenbosch, Schiedam, Utrecht and Zutphen. When we conduct an OLS regression analysis on these 15 observations - with city growth between 1300 and 1400 as the dependent variable - we find a positive coefficient of 0.142 for the BCL, which is insignificant and small compared to the coefficients in Tables 8 and 9 (the t-ratio equals $0.63)$. Initial population in 1300 yields a coefficient (standard error) of $-0.790(0.153)$.

There has been BCL-activity in Germany and Belgium too (e.g., Post, 1968). If we extend the sample by including BCL-presence in the German regions of Niedersachsen, North-Rhine Westphalia and Rhineland-Palatinate and in Belgium, we obtain a sample of 34 cities. Below we elaborate on this extension. The regression coefficient (standard error) for the BCLdummy now equals $0.226(0.205)$, which is still insignificant. Both sets of estimates suggest that it is unlikely that developments before the BCL mitigate our estimates.

\subsection{Hanseatic Trade}

The Hanseatic League was an association of cities that traded along the coast of Northern Europe. It was established in the 1150s in Lübeck. It stretched from the Baltic to the North Sea, including the Netherlands. Cities in the northern parts of the Netherlands were part of the League and trade took place along the Dutch rivers too. Deventer, Kampen and Zwolle were member cities. The influence of the Hanseatic League was different from the influence of the BCL. The main reason is that the impact of the Hanseatic League on the development of the Dutch economy was limited. The Hanseatic League was strong in Scandinavia, the Baltic and the northern part of Germany. The trade networks in the Netherlands were already established before the Hanseatic League became important (e.g., Slechte, 2010 and Schulte Beerbühl, 2011).

In Table 12 we investigate the impact of hanseatic trade on economic development in the period 1400-1560. There are twelve Dutch cities that can be identified as member cities: Arnhem, Bolsward, Deventer, Doesburg, Groningen, Harlingen, Hasselt, Kampen, Nijmegen, Oldenzaal, Roermond and Zutphen. We construct a dummy variable, which takes the value one if a city is a member. Column (1) shows the effect of this dummy variable on city growth in the period 1400-1560. The coefficient is not statistically different from zero. In column (2) we include the BCL-dummy. The estimate of the effect of BCL in this model is very similar 
to our previous results (column (1) of Table 8). The inclusion of other covariates in columns (3) does not alter this picture. Hence, it seems unlikely that the findings in the previous sections can be explained by hanseatic trade patterns.

\subsection{Placebo Tests of Instrumental Variable Identification}

In our main analysis we instrument the BCL by distance to Deventer. There could be other developments explaining our results. For example, Haarlem is often cited as one of the cities adopting the printing press in the 1460s (see Dittmar, 2011). This could influence our results, particularly those on literacy and book production. Also, Utrecht and Amsterdam have been important religious and trading cities in Dutch history, which merits a closer look. In addition, three cities outside the main area of our analysis might have been important: Antwerp as an important commercial center, Mainz which is located at the same river as Deventer and Louvain as an intellectual and religious center.

We have conducted a number of placebo tests in which we replace distance to Deventer with distance to Haarlem, Utrecht, Amsterdam, Antwerp, Mainz and Louvain. Table 13 reports the results of 2SLS estimates (first and second-stages and the F-tests for significance of the instrument) for book production, literacy, city growth and the Dutch Revolt. The first row copies the estimates for Deventer from the models reported in Table 6 columns (3) and (4) for book share, Table 7 columns (6) and (7) for literacy, Table 9 columns (3) and (4) for city growth and Table 10 columns (5) and (6) for Revolt. The next rows report the estimates of the placebo tests using the other cities as instruments for the BCL.

We first discuss the effects for replacing distance to Deventer with distance to the three important Dutch cities. Most first-stage estimates for the Dutch cities produce too low values to merit a sound 2SLS analysis, with two exceptions. First, distance to Utrecht is related to the book share. However, distance to Utrecht does not seem to matter for the other three outcomes. Second, distance to Haarlem is related to literacy but has the wrong sign.

For the foreign cities, the distance to Antwerp and Louvain seems to be important for book production and city growth. However, the first-stage estimates for these cities are positive, which suggests that an increase of the distance to Antwerp or Louvain increases the probability of the presence of a BCL-house. Increasing the distance to these cities in a northern direction is equivalent to decreasing the distance to Deventer, which probably explains the first and second-stage results. 
In conclusion, we believe that developments in other important cities of that time are unlikely to yield a convincing alternative explanation for the early development of the Netherlands.

\subsection{The Impact of Other Religious Orders}

In the medieval period a number of religious orders are dominant in Northern Europe. They all influenced society through the Roman Catholic Church. In the Netherlands there were five prominent monastic orders in the period 1400-1600. First, the Tertiarians lived outside cloistered communities. They had simple vows to certain prayers and observances of the order, which is much like the mixed life promoted by the BCL. Second, the Franciscans, who lived according to the regulations known as "The Rule of St. Francis". Third, the Cistercians, a religious orders of monks living in monasteries. ${ }^{23}$ Fourth, the Beghards and Beguines, who were religious communities living in a loose semi-monastic community but without formal vows. Finally, the monasteries of Modern Devotion are part of the BCL.

A concern with our results might be that these religious orders have been diffusing across the Netherlands in the same way the BCL did. If this would be the case, our instrumental variable approach would be invalid. To investigate whether or not this is the case, we have collected data on all monasteries belonging to these religious orders and assigned them to cities. All monasteries within 5 kilometers of a city are assigned to that city. ${ }^{24}$ Appendix A.2.8 provides more details about the data on the monasteries of these religious orders.

We repeated the previous estimations with the new type of monasteries instead of the BCL in the first and second stage just as in Table 6, column (3) for book share, Table 7, column (6) for literacy and Table 9, column (3)/ Table 10, column (5) for city growth and the Revolt. Table 14 presents the estimation results. The first row presents estimates when we include a dummy variable for the presence of a monastery regardless of its denomination. The coefficients and F-tests do not reveal a pattern in relation to our instrument distance to Deventer. The next row presents estimates for Modern Devotion. Not surprisingly we find negative and significant coefficients, which are in line with the estimates we obtained for the BCL-dummy. We interpret this outcome as evidence consistent with our earlier results because Geert Groote advocated the establishment of monasteries to downplay the criticism of heresy. These monasteries were strongly influenced by the body of thoughts and placed

\footnotetext{
${ }^{23}$ Barnebeck Andersen et al. (2011) examine the impact of the Cistercians on economic development in England and find an effect on cultural change.

${ }^{24}$ Using distances of 10 and 20 kilometers does not alter the picture.
} 
under rule by the BCL. For the other four types of monasteries there is no first stage. The coefficients are by and large not statistically different from zero and the F-tests do never pass the critical threshold of 10 . Our conclusion is that other religious orders did not have an impact on book production, literacy, economic growth and societal change in the Netherlands in the period $1400-1600$.

\subsection{Extending the Geographical Area}

The BCL also established houses in Germany and Belgium. We use the presence of the BCL to extend the geographical area of our analysis of economic growth. We have information for German regions (Niedersachsen, North-Rhine Westphalia and Rhineland-Palatinate) and for Belgium as a whole. This increases the number of observations from 67 to 91 . One important caveat applies. The population information for Germany is collected from Bairoch (1988), who only included relatively large cities. BCL-establishments were also present in relatively smaller cities.

Table 15 presents the estimates for a sample of 91 cities, which is equivalent to the estimates in Tables 8 and 9. The OLS estimates in columns (1) and (2) are consistent with the estimates in Table 8 and reveal a positive effect of the BCL on city growth in the period 1400-1560. In addition, the 2SLS approach, documented in columns (3) and (4), is also in line with the estimates presented in Table 9.

\subsection{The Legacy}

Our estimates show a long-lasting effect of the BCL on human capital, economic development and sweeping societal change. However, from the mid-seventeenth century onwards the formation of the Dutch Republic and the delayed spread of the Reformation led to the extinction of the BCL and the Modern Devotion movement in general. The virtues of Modern Devotion became widespread all over the country and the rest of Northern Europe and the economy does not benefit from the direct presence of the BCL anymore. In addition, the BCL more or less discontinued in 1568 when Pius V forced monastic rules upon the BCL. At the same time the ideas of the Reformation led to unrest in the BCL-community, which weakened its societal influence. The educational benefits of the BCL are documented in Figures $4 \mathrm{a}$ and $4 \mathrm{~b}$ in which we observe the difference between education levels in the Netherlands and Germany until at least 1800 . The strong economic development during the Dutch Golden Age from about 1580 onwards is well-documented (e.g., Israel, 1995).

Table 16 reports a set of OLS estimates in which we explain literacy rates in 1860 by the 
BCL and a set of 2SLS estimates in which we instrument the BCL by distance to Deventer. It is the same regression as the one reported in Table 7, but now for the full set of 67 cities (using the same set as in Table 7 produces similar conclusions as the ones drawn here). The OLS estimates in the columns (1)-(4) suggest no direct effect of the BCL on literacy in 1860. The other covariates produce plausible results in their relation to literacy. Also the 2SLS estimates, reported in columns (5)-(8), do not yield any significant causal effect of the BCL on literacy in 1860. What we do observe in this set of regressions is that the share of Protestants in the population has a positive effect on education. This is consistent with the findings of Becker and Woessmann (2009) for Germany for the same time period. We interpret these findings as a strong effect of the BCL in the take off of education (see the estimates in Table 7), but no further BCL-role in boosting education in more modern times (i.e., around the mid-nineteenth century).

Finally, Table 17 reports a set of OLS estimates in which we explain city growth up to 1795 . The specifications are similar to the ones reported in Table 8, except for the dependent variable which is now growth between 1400 and 1795. The estimated coefficients reported in Table 17 have the same sign compared to those presented in Table 8. However, the effect of the BCL is no longer statistically significant. Also the 2SLS estimates - reported in columns (4) and (5) - do not yield any significant coefficients, suggesting that the causal effect of the BCL on economic development is especially strong immediately after its foundation and diffusion in the Netherlands. In addition, the effect of BCL reduces towards zero if we focus the analysis on the period 1560-1795 (not shown in Table 17, but available upon request). This is consistent with the evidence documented in Acemoglu et al. (2005). They argue that sea-going trade from 1600 onwards (when the Dutch East India Company was established in Amsterdam) altered economic development in the Netherlands.

\section{Conclusion}

This paper has investigated the legacy of the Brethren of the Common Life on economic and social outcomes in the Netherlands. After the founding of the BCL by Geert Groote in Deventer in the late fourteenth century, the movement positively contributed to human capital formation and economic development in the Netherlands. Many historians have laid emphasis on the importance of the BCL for the development of Christian Humanism in Europe. In addition, others have related the BCL to early urbanization in the Netherlands and high levels of human capital. Hence, the BCL is likely to have contributed to the early development of 
the Netherlands and has formed a seedbed for the Dutch Revolt in 1572.

An important contribution of our analysis is that it is the first to document the importance of the BCL for economic and societal change. We provide a mechanism through which the BCL has influenced human capital formation by describing their activities in book production, educating young citizens and institutionalizing education. In addition, we show how the BCL has contributed to city growth. Finally, we offer a channel through which the BCL has led to pressure on the Habsburg rulers leading to the Dutch Revolt in 1572. We both show a direct effect through Christian Humanism and an indirect channel by means of high levels of education among ordinary citizens.

Our second main contribution is to empirically establish the impact of the BCL on economic and societal outcomes. In particular, we report estimates which suggest an effect of the BCL on book production and early literacy in the Netherlands in the sixteenth century. We also find evidence of stronger city growth in cities in the period 1400-1560 where BCL-houses had been established. Finally, we document estimates that reveal a role for the BCL in the Dutch Revolt. Cities where the BCL was present were more likely to join the Revolt and also joined the Revolt at an earlier date.

Overall our mechanism and empirical evidence shows that the BCL has been an important factor for the early development of the Netherlands. This research offers an explanation for why the Netherlands was the first country on the rise in the development of Europe by filling the time gap of about 200 years of European history.

\section{References}

Acemoglu, D., S. Johnson and J. Robinson (2005), "The Rise of Europe: Atlantic Trade, Institutional Change, and Economic Growth," American Economic Review, vol. 95, no. 3, pp. 546-579.

Angrist, J.D. and A.B. Krueger (1992), "The Effect of Age at School Entry on Educational Attainment: An Application of Instrumental Variables with Moments from Two Samples," Journal of the American Statistical Association, vol. 87, no. 418, pp. 328336.

Bairoch, P. (1988), Cities and Economic Development, University of Chicago Press: Chicago, IL.

Bairoch, P., J. Batou and P. Chèvre (1998), The Population of European Cities, 800-1850, Librairie Droz: Genève.

Barnebeck Andersen, T., J. Bentzen, C.-J. Dalgaard and P. Sharp (2011), "Religious Orders and Growth through Cultural Change in Pre-Industrial England," Discussion Paper No. 11-07, Department of Economics, University of Copenhagen.

Barro, R.J. and R.M. McCleary (2005), "Which Countries Have State Religions," Quarterly 
Journal of Economics, vol. 120, no. 4, pp. 1331-1370.

Baten, J. and J.L. van Zanden (2008), "Book Production and the Onset of Modern Economic Growth," Journal of Economic Growth, vol. 13, no. 3, pp. 217-235.

Becker, S.O. and L. Woessmann (2009), "Was Weber Wrong? A Human Capital Theory of Protestant Economic History," Quarterly Journal of Economics, vol. 124, no. 2, pp. 531-596.

Blockmans, W.P. (1993), "De Vorming van een Politieke Unie (Veertiende-Zestiende Eeuw)," in: J.C.H. Blom and E. Lamberts, eds., Geschiedenis van de Nederlanden, HB Uitgevers: Baarn, pp. 46-113.

Blom, J.C.H. and E. Lamberts (1993), Geschiedenis van de Nederlanden, HB Uitgevers: Baarn.

Botticini, M and Z. Eckstein, 2007, "From Farmers to Merchants, Conversions and Diaspora: Human Capital and Jewish History," Journal of the European Economic Association, vol. 5, no. 5, pp. 885-926.

Boucekkine, R., D. Peeters and D. de la Croix (2007), "Early Literacy Achievements, Population Density, and the Transition to Modern Growth," Journal of the European Economic Association, vol. 5, no. 1, pp. 183-226.

Braudel, F. (1979), Civilisation, Economie et Capitalisme, Armand Colin: Paris.

Buringh, E. and J.L. van Zanden (2009), "Charting the "Rise of the West": Manuscripts and Printed Books in Europe, A Long-Term Perspective from the Sixth through Eighteenth Centuries," Journal of Economic History, vol. 69, no. 2, pp. 409-445.

Cantoni, D. (2012), "Adopting a New Religion: The Case of Protestantism in 16th Century Germany," Economic Journal, vol. 122, no. 560, pp. 502-531.

Cipolla, C. (1969), Literacy and Development in the West, Penguin Books: London.

Congleton, R.D. (2008), "America's Neglected Debt to the Dutch, An Institutional Perspective," Constitutional Political Economy, vol. 19, no. 1, pp. 35-60.

DeLong, J. Bradford and A. Shleifer (1993), "Princes and Merchants: European City Growth before the Industrial Revolution," Journal of Law and Economics, vol. 36, no. 2, pp. 671-702.

De Graaf, R. (2004), Oorlog, Mijn Arme Schapen. Een Andere Kijk op de Tachtigjarige Oorlog 1565-1648, Uitgeverij Van Wijnen: Franeker.

De Vries, J. (1984), European Urbanization, 1500-1800, Harvard University Press: Cambridge MA.

De Vries, J. and A. van de Woude (1997), The First Modern Economy: Success, Failure, and Perseverance of the Dutch Economy, 1500-1815, Cambridge University Press: Cambridge.

Dittmar, J. (2011), "Information Technology and Economic Change: The Impact of the Printing Press," Quarterly Journal of Economics, vol. 126, no. 3, pp. 1133-1172.

Fuller, R. (1995), The Brotherhood of the Common Life and His Influence, State University of New York Press: New York.

Galor, O. (2010), "The 2008 Klein Lecture: "Comparative Economic Development: Insights from Unified Growth Theory," International Economic Review, vol. 51, no. 1, pp. 1-44.

Galor, O. (2011), "Inequality, Human Capital Formation and the Process of Development," in: E.A. Hanushek, S.J. Machin and L. Woessmann, eds., Handbook of the Economics of Education, North Holland: Amsterdam, pp. 441-493.

Galor, O. and O. Moav (2006), "Das Human Kapital: A Theory of the Demise of the Class Structure," Review of Economics Studies, vol. 73, no. 1, pp. 85-117.

Galor, O. and D.N. Weil (1999), "From Malthusian Stagnation to Modern Growth," American Economic Review, vol. 89, no. 2, pp. 150-154.

Gem, S.H. (1907), Hidden Saints. A Study of the Brothers of the Common Life, Society for 
Promoting Christian Knowledge Subjects: Oxford.

Glaeser, E.L. and S. Glendon (1998), "Incentive, Predestination and Free Will," Economic Inquiry, vol. 36, no. 3, pp. 429-443.

Goldin, C. and L.F. Katz (1998), "The Origins and Technology-Skill Complementarity," Quarterly Journal of Economics, vol. 113, no. 2, pp. 693-732.

Goldin, C. and L.F. Katz (2008), The Race Between Education and Technology, Harvard University Press: Cambridge, MA.

Hart, S. (1976), Geschrift en Getal, Amicitia: Bloemendaal.

Haselden, R.B. (1939), "A Scribe and Printer in the Fifteenth Century," Huntington Library Quarterly, vol. 2, no. 2, pp. 205-211.

Henkel, J.S. (1968), "School Organizational Patterns of the Brethren of the Common Life," in K.A. Strand, ed., Essays on the Northern Renaissance, Ann Arbor Publishers: Michigan, pp. 35-50.

Hyma, A. (1924), The Christian Renaissance: A History of the Devotia Moderna, Kessinger Publishing: Whitefish, Montana.

Hyma, A. (1950), The Brethren of the Common Life, Wm. B. Eerdmans Publishing Company: Grand Rapids, Michigan.

Hyma, A. (1951), Renaissance to Reformation, Wm. B. Eerdmans Publishing Company: Grand Rapids, Michigan.

Hyma, A. (1968), "Introduction: The "Devotia Moderna" and the Humanists," in K.A. Strand, ed., Essays on the Northern Renaissance, Ann Arbor Publishers: Michigan, pp. 9-31.

Israel, J.I. (1995), The Dutch Republic. Its Rise, Greatness, and Fall 1477-1806, Claredon Press: Oxford.

Kaptein, H.J.M. (1998), De Hollandse Textielnijverheid, 1350-1600: Conjunctuur en Continuïteit, Uitgeverij Verloren: Hilversum

King, S. (1992), "The Sisters of the Common Life at Deventer, 1374-1418: A New Beginning?," Mystics Quarterly, vol. 18, no. 4, pp. 120-130.

Kuijpers, E. (1997), "Lezen en Schrijven: Onderzoek naar het Alfabetiseringsniveau in Zeventiende-Eeuws Amsterdam," Tijdschrift voor Sociale Geschiedenis, vol. 23, no. 4, pp. 490-522.

Laurie, S.S. (1896), "The Renaissance and the School, 1440-1580," The School Review, vol. 4, no. 3, pp. 140-148.

Leibell J.F. (1924), "The Church and the Humanism," The Catholic Historical Review, vol. 10 , no. 3, pp. 331-352.

Lourens, P. and J. Lucassen (1995), Inwonertallen van Nederlandse Steden, ca. 1300-1800, NEHA: Amsterdam.

McCarrel, F. (1934), "An Abstract of the Development of the Training School," Peabody Journal of Education, vol. 11, no. 5, pp. 212-215.

McCleary, R.M. and R.J. Barro (2006), "Religion and Economy," Journal of Economic Perspectives, vol. 20, no. 2, pp. 49-72

Parker, G. (1977), The Dutch Revolt, Cornell University Press: Ithaca, NY.

Pijper, F. (1914), "De Invloed van de Broeders des Gemeenen Levens op de Schoolstichting van Calvijn," Kerkhistorische Opstellen van het Gezelschap, pp. 116-117.

Post, R.R. (1954), Scholen en Ondewijs in Nederland Gedurende de Middeleeuwen, Uitgeverij Het Spectrum: Utrecht/Antwerpen.

Post, R.R (1968), The Modern Devotion. Confrontation with Reformation and Humanism, E.J. Brill: Leiden.

Schoeck, R.J. (1988), Erasmus Grandescens: The Growth of a Humanist's Mind and Spirituality, De Graaf: Nieuwkoop. 
Schulte Beerbühl, M. (2011), Das Netzwerk der Hanse, Institute of European History: Mainz.

Slechte, H. (2010), Geschiedenis van Deventer: Oorsprong en Middeleeuwen, Walburg Pers: Zutphen.

Strand K.A. (1968), "The Brethren of the Common Life and Fifteenth-Century Printing," in K.A. Strand, ed., Essays on the Northern Renaissance, Michigan: Ann Arbor Publishers, pp. 51-64.

Unger, R.W. (1978), Dutch Shipbuilding before 1800: Ships and Guilds, Van Gorcum: Assen.

Unger, R.W. (2001), A History of Brewing in Holland, 900-1900: Economy, Technology and the State, Brill Academic Publishers: Leiden.

Van Bavel, B.J.P. (2002), "People and Land: Rural Population Developments and Property Structures in the Low Countries, c.1300- c.1600," Continuity and Change, vol. 17, no. 1, pp. 9-37.

Van Bavel, B.J.P. and J.L. van Zanden (2004), "The Jump-Start of the Holland Economy during the Late-Medieval Crisis, c.1350-c.1500," Economic History Review, vol. 57, no. 3, pp. 503-532.

Van der Wee, H. (1971), "The Economy as a Factor in the Revolt of the Southern Netherlands," Acta Historiae Neerlandica, vol. 5, pp. 52-67.

Van Engen, J. (2008), Sisters and Brothers of the Common Life. The Devotia Moderna and the World of the Late Middle Ages, University of Pennsylvania Press: Philadelphia.

Van Nierop, H.F.K. (1999), Het Verraad van het Noorderkwartier: Oorlog, Terreur en Recht in de Nederlandse Opstand, Prometheus: Amsterdam.

Van Zanden, J.L. (1993), The Rise and Decline of Holland's Economy, University of Manchester Press: Manchester.

Woltjer, J.J. (2011), Op Weg naar Tachtig Jaar Oorlog, Het Verhaal van de Eeuw waarin Ons Land Ontstond, Uitgeverij Balans: Amsterdam. 


\section{Appendix}

This section provides detailed information about the data sources used in the empirical analysis and about the construction of variables.

\section{A.1. Variable Definitions}

\begin{tabular}{|c|c|}
\hline Variable & Definition \\
\hline Growth 1300-1400 & $\begin{array}{l}\text { Growth of city populations from } 1300 \text { to } 1400 \text {. Source: Bairoch } \\
\text { (1988). }\end{array}$ \\
\hline Growth 1400-1560 & $\begin{array}{l}\text { Growth of city populations from } 1400 \text { to } 1560 \text {. Source: Lourens } \\
\text { and Lucassen (1995). See Section A.2.2. }\end{array}$ \\
\hline Growth 1400-1795 & $\begin{array}{l}\text { Growth of city populations from } 1400 \text { to } 1795 \text {. Source: Lourens } \\
\text { and Lucassen (1995). See Section A.2.2. }\end{array}$ \\
\hline Log population 1300 & Log of city population in 1300 . \\
\hline Log population 1400 & Log of city population in 1400 . \\
\hline Revolt & $\begin{array}{l}\text { The lag in days of the diffusion of the Dutch Revolt from the } \\
\text { start in Brielle on } 1 \text { April 1572. Source: Parker (1977) and De } \\
\text { Graaf (2004). See Section A.2.4. }\end{array}$ \\
\hline
\end{tabular}

Book share

The number of printed book editions as a share of total printed book editions in the Netherlands from 1470 to 1500 . See http://www.bl.uk/catalogues/istc/index.html. Source: Incunabula Short Title Catalogue.

Literacy $1600 \quad$ Estimated literacy rates around 1600 based on Hart (1976). Source: Simon Hart's inventory at the Amsterdam Municipality Archives and Hart (1976). See Section A.2.1.

BCL

Dist. Deventer

Dummy variable which equals one if there is a BCL-house in the city. See Section A.2.3.

Roman

Distance to the city of Deventer in kilometers. See Section A.2.6.

Distance to the closest Roman settlement and Roman trade route in kilometers. See Section A.2.6.

Sea

Dummy variable which equals one if the city is on the sea coast.

River

Dummy variable which equals one if the city is along one of the main rivers.

Schools before 1400 Dummy variable which equals one if there is a school before 1400 in a city. Source: Post (1954).

Hanseatic League Dummy variable which equals one if the city is associated with Hanseatic League. Source: Schulte Beerbühl (2011) and information at http://en.wikipedia.org/wiki/Hanseatic_League.

Literacy $1860 \quad$ Estimated male literacy from HSN. Release HSNGEB.01. See Section A.2.1. 


\section{A.2. Data and Variable Construction}

This section provides details about the data sources and the construction of variables.

\section{A.2.1. Literacy}

Information about early literacy in the Netherlands is based on two different sources. Before 1810 we rely on the Amsterdam Marriage Registers. Our proxy for literacy is the percentage of brides and grooms who hand signed the register when they got married. After 1810 we rely on signatures on birth certificates to proxy adult literacy in a similar way.

Early literacy data are collected from the Amsterdam Marriage Registers which includes information about brides and grooms starting in the late sixteenth century. The registers include both information on the place of birth of brides and grooms and whether or not they signed the register or stamped by a finger print. If people were illiterate, finger prints were used to sign for the marriage. There are around 928,000 marriages in the period 1580-1810, so about two million observations. Since we know the place of birth of people, we obtain literacy information for 33 cities from 1600 onwards. The data reveal that the percentage of non-Amsterdam born brides and grooms ranges from around 40 in the late sixteenth to about 70 in the early seventeenth century. These numbers also include foreign born brides and grooms, mainly from Germany. This allows us to analyze literacy for 20 cities in Germany.

Table A.2.1: Archive numbers of marriage registers

\begin{tabular}{|c|c|}
\hline 2 & Documents on individual items \\
\hline 2.5 .6 & Historical demography \\
\hline 2.5.6.2 & Treatment of marriage registers \\
\hline 2.5.6.2.1 & The Netherlands \\
\hline 645 & Total state, graphics, maps - 1 folder \\
\hline $646-648$ & Gelderland \\
\hline $649-651$ & Noord-Holland \\
\hline $652-653$ & Overijssel \\
\hline $654-656$ & Zuid-Holland \\
\hline $658-660$ & Friesland \\
\hline $661-662$ & Noord-Brabant \\
\hline $663-664$ & Groningen \\
\hline $665-666$ & Zeeland \\
\hline 667 & Drenthe \\
\hline $668-669$ & Limburg \\
\hline 2.5.6.2.2 & Germany \\
\hline 670 & Total state, graphics, maps - 1 folder \\
\hline $671-673$ & Schleswig-Holstein \\
\hline 674 & Hamburg \\
\hline 675 & Bremen \\
\hline $676-683$ & Niedersachsen \\
\hline $684-685$ & Oost Friesland \\
\hline $686-696$ & Detailed personal information on Oost Friesland \\
\hline $697-700$ & Nordrhein Westfalen \\
\hline 701 & Hessen \\
\hline 702 & Rheinland-Pfalz and Saarland \\
\hline 703 & Baden-Württemberg \\
\hline 704 & Bayern \\
\hline 705 & East-Germany \\
\hline
\end{tabular}

Source: Amsterdam Archives. Number 883: Archief van dr. S. Hart, Gemeentearchivaris 
The data are not available in electronic format. Simon Hart, the late keeper of the Amsterdam archives, has structured the files in 25-year periods from 1600 onwards (Hart, 1976). This way Hart built an archive on marriage registers, which is available for research in the Amsterdam Archives. The archive is structured by cities and accessible under inventory number 883: Archief van dr. S. Hart, Gemeentearchivaris. From these documents we collected literacy data for 33 cities in the Netherlands for six provinces (Friesland, Gelderland, Groningen, Noord-Holland, Overijssel and Zuid-Holland). These provinces are defined according to their present structure and encompass the Dutch Seven Provinces of that time. Information about German cities is available for what are now three Länder: Lower Saxony, Schleswig-Holstein and North Rhine-Westphalia. A detailed list of archive numbers matched to provinces is presented in Table A.2.1. The photocopied records are available upon request.

After 1810 we base our calculations on data from birth registers for all main cities in the Netherlands. These data are available from the Historical Sample of the Netherlands (HSN) at the International Institute of Social History (IISH). We used the release HSNGEB.01. An advantage of these data is that it provides information about the date and age of the father, whether or not the father is illiterate and whether or not the register was signed or not. There are about 78,000 records from 1811 onwards spanning a period of about 100 years. The geographic aggregation is at the town level, which allows us to aggregate data for about 1,100 municipalities in the Netherlands around 1860. For each observation we have the fathers' age, his state of literacy, birth date and place of residence. We would like to pinpoint one year but do not have enough observations if we only choose birth certificates from for example 1860. For this reason for each observation we estimated whether or not the father is likely to be alive in a certain year using the average life expectancy in 1850 . To increase the sample size we took 1860 as the midpoint of a twenty year period and construct a dummy variable that takes the value one if the father is likely to be alive in between 1841 and 1880 .

\begin{tabular}{|c|c|c|c|}
\hline & 1810 & 1850 & 1890 \\
\hline Groningen & 0.84 & 0.90 & 0.97 \\
\hline Friesland & 0.86 & 0.90 & 0.95 \\
\hline Drenthe & 0.87 & 0.90 & 0.93 \\
\hline Overijssel & 0.69 & 0.81 & 0.91 \\
\hline Gelderland & 0.73 & 0.82 & 0.91 \\
\hline Utrecht & 0.72 & 0.78 & 0.92 \\
\hline Noord-Holland & 0.84 & 0.92 & 0.97 \\
\hline Zuid-Holland & 0.80 & 0.88 & 0.96 \\
\hline Zeeland & 0.74 & 0.77 & 0.89 \\
\hline Noord-Brabant & 0.67 & 0.71 & 0.85 \\
\hline Limburg & 0.58 & 0.73 & 0.91 \\
\hline
\end{tabular}

Next, we aggregate this information to the current 450 municipalities in the Netherlands to increase the number of observations for each city. If the number of observations for a municipality in 1860 is less than 20, it is replaced by the 1860 literacy data computed for the contemporary municipality definition. About 250 replacements are made at this stage (out of 1,100 municipalities). Literacy data for the eleven provinces in the nineteenth century are presented in Table A.2.2. The literacy numbers for the 33 Dutch cities for which we have data from 1600 onwards are presented in Table A.2.3. 
Table A.2.3: Male literacy data for Dutch cities, 1600-1860

\begin{tabular}{|c|c|c|c|c|c|}
\hline Province & City & 1600 & 1675 & 1750 & 1860 \\
\hline NOORD-HOLLAND & Alkmaar & 0.64 & 0.86 & 0.96 & 0.97 \\
\hline GELDERLAND & Arnhem & 0.75 & 0.81 & 0.90 & 0.91 \\
\hline GELDERLAND & Borculo & 0.84 & 0.90 & 0.81 & 0.96 \\
\hline ZUID-HOLLAND & Delft & 0.64 & 0.75 & 0.92 & 0.94 \\
\hline OVERIJSSEL & Deventer & 0.79 & 0.91 & 0.90 & 0.93 \\
\hline GELDERLAND & Doesburg & 0.70 & 0.77 & 0.90 & 0.73 \\
\hline FRIESLAND & Dokkum & 0.44 & 0.60 & 0.83 & 0.90 \\
\hline ZUID-HOLLAND & Dordrecht & 0.73 & 0.74 & 0.87 & 0.93 \\
\hline NOORD-HOLLAND & Enkhuizen & 0.59 & 0.78 & 0.92 & 0.93 \\
\hline FRIESLAND & Franeker & 0.56 & 0.77 & 0.90 & 0.86 \\
\hline GELDERLAND & Groenlo & 0.73 & 0.90 & 0.92 & 0.84 \\
\hline GRONINGEN & Groningen & 0.63 & 0.76 & 0.85 & 0.93 \\
\hline NOORD-HOLLAND & Haarlem & 0.66 & 0.68 & 0.77 & 0.91 \\
\hline GELDERLAND & Harderwijk & 0.70 & 0.68 & 0.88 & 0.89 \\
\hline FRIESLAND & Harlingen & 0.51 & 0.68 & 0.83 & 0.87 \\
\hline NOORD-HOLLAND & Hoorn & 0.57 & 0.80 & 0.75 & 0.88 \\
\hline OVERIJSSEL & Kampen & 0.69 & 0.72 & 0.88 & 0.83 \\
\hline FRIESLAND & Leeuwarden & 0.60 & 0.76 & 0.84 & 0.94 \\
\hline ZUID-HOLLAND & Leiden & 0.64 & 0.68 & 0.73 & 0.79 \\
\hline NOORD-HOLLAND & Naarden & 0.70 & 0.51 & 0.80 & 0.91 \\
\hline GELDERLAND & Nijkerk & 0.54 & 0.88 & 0.77 & 0.68 \\
\hline GELDERLAND & Nijmegen & 0.74 & 0.74 & 0.81 & 0.85 \\
\hline OVERIJSSEL & Oldenzaal & 0.62 & 0.69 & 0.74 & 0.70 \\
\hline OVERIJSSEL & Ootmarsum & 0.80 & 0.77 & 0.94 & 0.94 \\
\hline ZUID-HOLLAND & Rotterdam & 0.67 & 0.77 & 0.84 & 0.97 \\
\hline OVERIJSSEL & Almelo & 0.68 & 0.63 & 0.86 & 0.77 \\
\hline FRIESLAND & Terschelling & 0.51 & 0.79 & 0.71 & 0.97 \\
\hline NOORD-HOLLAND & Texel & 0.63 & 0.81 & 1.00 & 0.95 \\
\hline GELDERLAND & Tiel & 0.68 & 0.79 & 0.85 & 0.76 \\
\hline FRIESLAND & Vlieland & 0.48 & 0.77 & 1.00 & 1.00 \\
\hline NOORD-HOLLAND & Weesp & 0.69 & 0.71 & 0.88 & 0.83 \\
\hline GELDERLAND & Zutphen & 0.80 & 0.84 & 0.95 & 0.93 \\
\hline OVERIJSSEL & Zwolle & 0.69 & 0.77 & 0.89 & 0.94 \\
\hline
\end{tabular}

\section{A.2.2. Population}

Lourens and Lucassen (1995) present population data on selected Dutch cities from the fourteenth century onwards. The earliest date for which they provide information is 1364 . However, comparable population information (and sometimes census) data is not always available for the same years. For this reason they present comparable data for 155 cities for four years: 1400, 1560, 1630 and 1795. For almost half of these cities the 1400 and 1560 data are estimates. We base our sample on cities with 1,000 or more inhabitants because many of the smaller cities the population numbers are set to 500. Table 3 presents the 10 largest cities in 1400,1560 and 1800. For population figures before 1400 we rely on Bairoch (1988).

\section{A.2.3. Brethren of the Common Life}

The Brethren of the Common Life (BCL) originated from the city of Deventer. The first house was established in 1374 in Deventer and later followed by Amersfoort in 1395 and Zwolle in 1396. During the fifteenth century the organization spread over the Netherlands, contemporary Belgium and the Western part of Germany. The BCL consists of three forms of communities: brother houses, sister houses and schools. There were hostels for (poor) students as well. In some cases there were multiple houses in one city.

Our main BCL indicator measures BCL activity in terms of houses and /or schools in a city. It is constructed as a dummy variable that takes the value one if there has been a brother house, sister house or a school. There is not a single source that presents information about 
the BCL establishments by city. We made use of different sources: Hyma (1924; 1950; 1951 and 1958), Post (1968), Fuller (1995) and Van Engen (2008). Figure A.2.1 presents the 35 BCL-cities on a map.

In addition, we apply information about the number of houses. Figure A.2.1. shows in brackets the number of BCL-houses if it exceeds one. There are 15 cities with more than one BCL-house: Zwolle (8), Deventer (7), Doesburg (4), Utrecht (4), Amersfoort (3), Delft (3), Groningen (3), Harderwijk (3), 's- Hertogenbosch (3), Zutphen (3), Gouda (2), Hattem (2), Kampen (2), Lochem (2), and Nijmegen (2).

\section{Figure A.2.1. BCL-cities in the Netherlands}

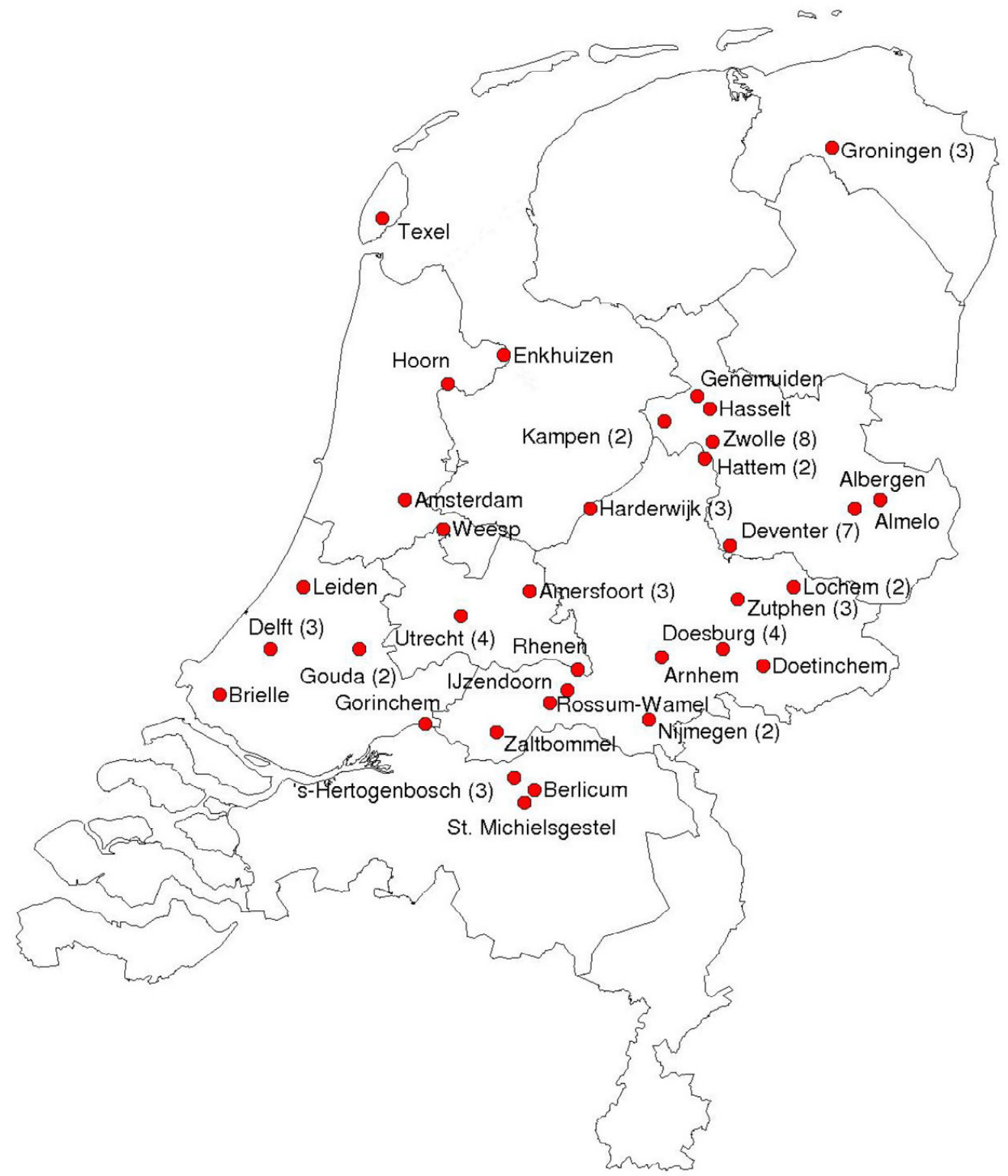




\section{A.2.4. The Dutch Revolt}

We constructed a diffusion variable to measure the Dutch Revolt using information on the date of uprise in a city after rebels took over Brielle from Alba on 1 of April 1572. Brielle takes the value 0 . For each city, the revolt variable is calculated as number of days it took before the revolt took place in that city after 1 April. Our source is De Graaf (2004). For some towns not listed by De Graaf we used a map from Parker (1977, Figure 7). The list of cities and the revolt gap in terms of days is presented in Table A.2.4. Figure 5 in Section 2 presents a map with all cities and the days it took before cities started to revolt against the Spanish rulers.

Table A.2.4: The diffusion of the Dutch Revolt in 1572

\begin{tabular}{lll}
\hline Province & City & Days \\
\hline ZUID-HOLLAND & Brielle & 0 \\
ZEELAND & Vlissingen & 21 \\
ZEELAND & Arnemuiden & 28 \\
ZEELAND & Veere & 33 \\
NOORD-HOLLAND & Enkhuizen & 50 \\
NOORD-HOLLAND & Medembik & 56 \\
GELDERLAND & Zutphen & 69 \\
NOORD-HOLLAND & Hoorn & 72 \\
GELDERLAND & Doesburg & 73 \\
GELDERLAND & Doetinchem & 73 \\
UTRECHT & Oudewater & 79 \\
NOORD-HOLLAND & Alkmaar & 80 \\
ZUID-HOLLAND & Gouda & 80 \\
ZUID-HOLLAND & Dordrecht & 82 \\
ZUID-HOLLAND & Leiden & 82 \\
NOORD-HOLLAND & Monnikendam & 86 \\
GELDERLAND & Harderwijk & 93 \\
GELDERLAND & Elburg & 94 \\
ZUID-HOLLAND & Schoonhoven & 97 \\
GELDERLAND & Buren & 100 \\
NOORD-HOLLAND & Naarden & 102 \\
GELDERLAND & Hattem & 104 \\
NOORD-HOLLAND & Haarlem & 92 \\
OVERIJSSEL & Oldenzaal & 110 \\
ZUID-HOLLAND & Rotterdam & 110 \\
LIMBURG & Roermond & 112 \\
ZUID-HOLLAND & Delft & 115 \\
GELDERLAND & Bommel & 119 \\
UTRECHT & Woerden & 127 \\
OVERIJSSEL & Kampen & 130 \\
OVERIJSSEL & Genemuiden & 131 \\
OVERISSEL & Meppel & 132 \\
OVERIJSSEL & Zwolle & 132 \\
FRIESLAND & Sneek & 137 \\
GELDERLAND & Amersfoort & 137 \\
FRIESLAND & Bolsward & 146 \\
LIMBURG & Weert & 146 \\
FRIESLAND & Franeker & 147 \\
\hline & & \\
& &
\end{tabular}




\section{A.2.5. Census}

We use the Volkstellingen Archief (Census) for information about population and households from 1795 onwards. We collected all information for 1859 , which is the first round available that presents data at the municipality level. The 1859 data present information on about 1,200 local area units. This information was matched to HSN data explained above. The long-run analysis in Section 5.7 is based on this merged data set.

\section{A.2.6. Distance Calculations}

We use latitude and longitude values to calculate distance 'as the crow flies' measures. Distance to city $X$ is calculated as:

$$
\begin{aligned}
\text { Distance to city } X= & 6378.7 * \operatorname{acos}((\sin (\text { latitude } / 57.2958) * \sin (\text { latitude of city X/57.2958) })+ \\
& (\cos (\text { latitude/57.2958)* } \cos (\text { latitude of city X/57.2958) } \\
& * \cos ((\text { longitude/57.2958) }-(\text { longitude of city X/57.2958) }))),
\end{aligned}
$$

where acos, sin, cos notify arc-cosine, sine and cosine respectively. To calculate the distance to the nearest Roman trade route we have made use of the list of Roman Settlements in the Netherlands and the Peutinger map that shows the major trade routes in Roman times. Both sources are matched to obtain a list of towns for which we could obtain latitude and longitude values. Some towns are not matched to a modern settlement name. We omit those. Table A.2.5 lists the cities. The complete list of settlements is available at:

http://www.romanaqueducts.info/romeineninnederland/rinn_bijlagen.htm.

In Section 5.6 when we present the results including the hinterland of the Netherlands we include some major German and Belgian cities. To calculate the closest distance to Roman settlement in Belgium we used the following Roman cities: Kortrijk, Bavay, Cambrai, Dinant, Ciney, Gembloux, Hainaut, Leuze, Ronse, Tongeren, Tournai, Vise, Liege, Huy. For Germany we used the following set: Aachen, Augsburg, Bingen, Bonn, Cologne, Koblenz, Lahnau, Mainz, Neuss, Trier, Xanten and Zülpich.

Table A.2.5: List of Roman settlements according to Peutinger Map

\begin{tabular}{lll}
\hline Modern name & Classical name & Name in map of Peutinger \\
\hline Alphen a/d Rijn & Albaniana & Albanianu \\
Blerick & Blariaco & Blariaco \\
Kesteren & Carvo & Carvone \\
Arnhem-Meinerswijk & Castra Herculis & Castra Herculis \\
Cuijk & Ceuclum & Ceuclum \\
Heerlen & Coriovallum & Cortovallio \\
Bunnik-Vechten & Fectio & Fletione \\
Voorburg (ZH) & Forum Hadriani & Foro Adriani \\
Rossum (GLD) & Grinnes & Grinnibus \\
Woerden & Laurum / Laurium & Lauri \\
Wijk bij Duurstede & Levefanum & Levefano \\
Katwijk-Brittenburg & Lugdunum & Lugduno \\
Maurik & Mannaricium & \\
Leiden-Roomburg & Matilo & Matilone \\
Zwammerdam & Nigrum Pullum & Nigropullo \\
Valkenburg (ZH) & Praetorium Agrippinae & Pretoriu.Agrippine \\
Utrecht & Traiectum & - \\
Nijmegen & Batavodorum & Nouiomagi \\
\hline & & \\
\hline
\end{tabular}




\section{A.2.7. Network Data}

The network data for influential people living in the fifteenth and sixteenth century are collected from various sources. We relied on books about the BCL, the Reformation and the compendium that gives short biographical information on people who lived in the times of Erasmus. In codifying the data we followed four simple rules:

1. Two persons are friends, colleagues, studied in the same school, teacher-student relation or a similar close relation;

2. Two persons have met once or twice and keep in contact afterwards;

3. Two persons have met once and kept contact from time to time through third person or letters; and

4. Two persons have never met but exchanged many letters on certain matters through time.

If one of the above rules is met we coded a link between two people. If a person studied in a BCL school, lived in a BCL house or took part in the organization we coded this person as affiliated to the BCL. The people in the network are shown in Figure 3 and a complete list of people with affiliations and additional information about their work and activities is available upon request.

\section{A.2.8. Monastery Data}

The monastery data comes from the list of all known monasteries in the Netherlands. The "kloosterlijst" is a public database that is provided by Free University Amsterdam and can be accessed at http://www2.let.vu.nl/oz/kloosterlijst/. The database and the accompanying information are in Dutch.

The dataset has information on the location and type of about 700 monasteries in the Netherlands. We only have about 400 monasteries that are associated to a Dutch city. Others were generally established in smaller towns or in the countryside. To include most of the monasteries in the list we used an approach that counts the number of monasteries within a 5 $\mathrm{km}$ diameter to each city in our sample. We choose $5 \mathrm{~km}$ because a person with a normal walking speed can walk about 5 kilometers in an hour. If there is a monastery within the walking distance of 5 kilometers in a city the monastery variables takes the value 1 and if not 0 .

There are more than 50 different types of male and female monasteries. Most of the monasteries can be clustered into main orders. We group the monasteries into five main orders with no distinction in gender: Modern Devotion monasteries ${ }^{25}$; Franciscans; Tertiarians; Beghards; and Cistercians. As Table A.2.6. shows, the five main orders make up about 60 percent of all monasteries. The most common orders are the monasteries that are associated with Modern Devotion and the Tertiarians.

Table A.2.6: The five most important monastic orders

\begin{tabular}{lrr}
\hline Order of monasteries & Number of Monastery & Percentage in total \\
\hline Modern Devotion & 143 & 20.31 \\
Tertiarians & 140 & 19.88 \\
Beghards & 62 & 8.80 \\
Cistercians & 33 & 4.69 \\
Franciscans & 29 & 4.12 \\
\hline
\end{tabular}

\footnotetext{
${ }^{25}$ This group includes Augustinian Canons, monasteries associated with Windesheim Congregation and Brother and Sisters of the Common Life.
} 
Figure 1: A map of the Netherlands in the fifteenth century

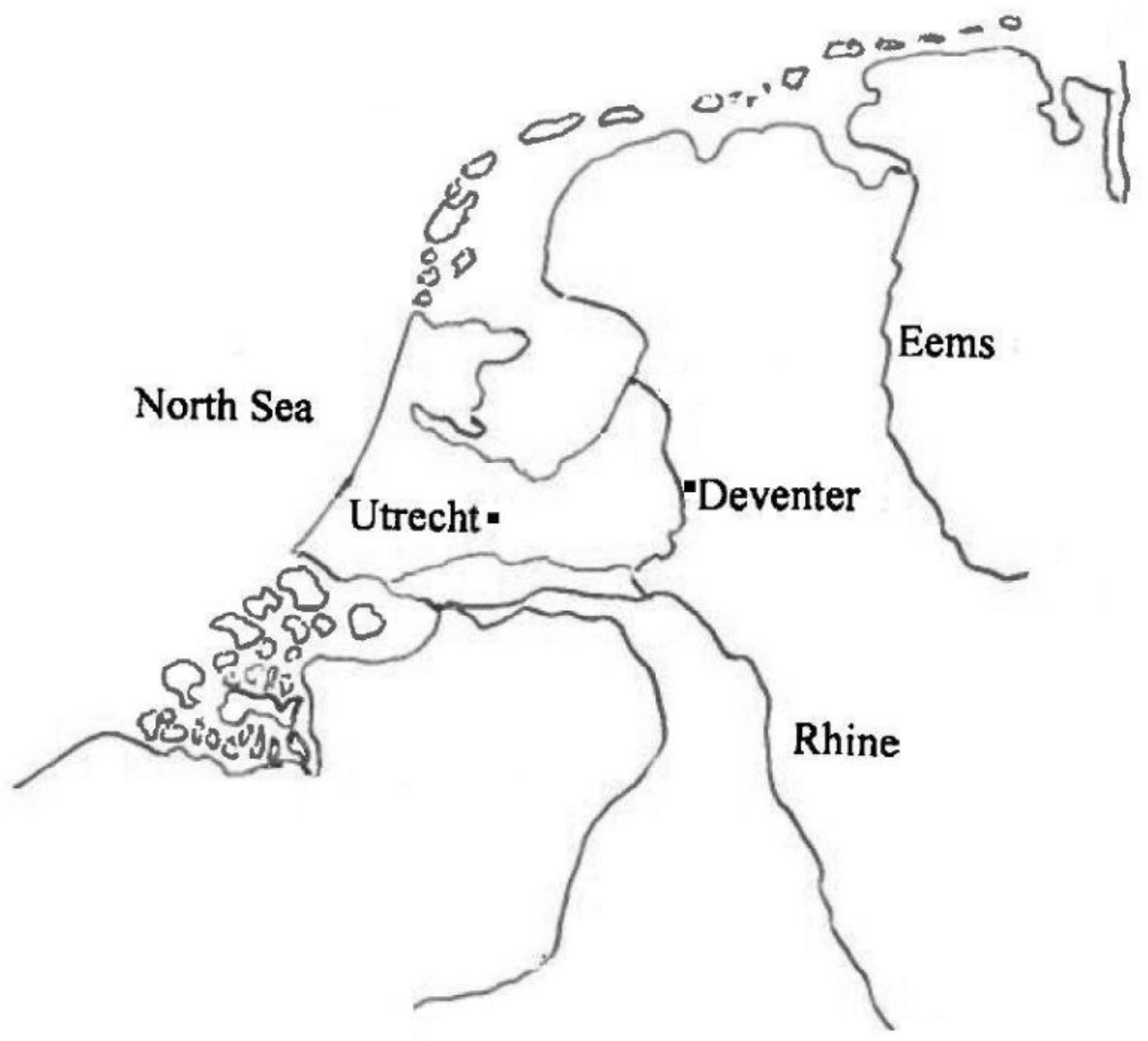




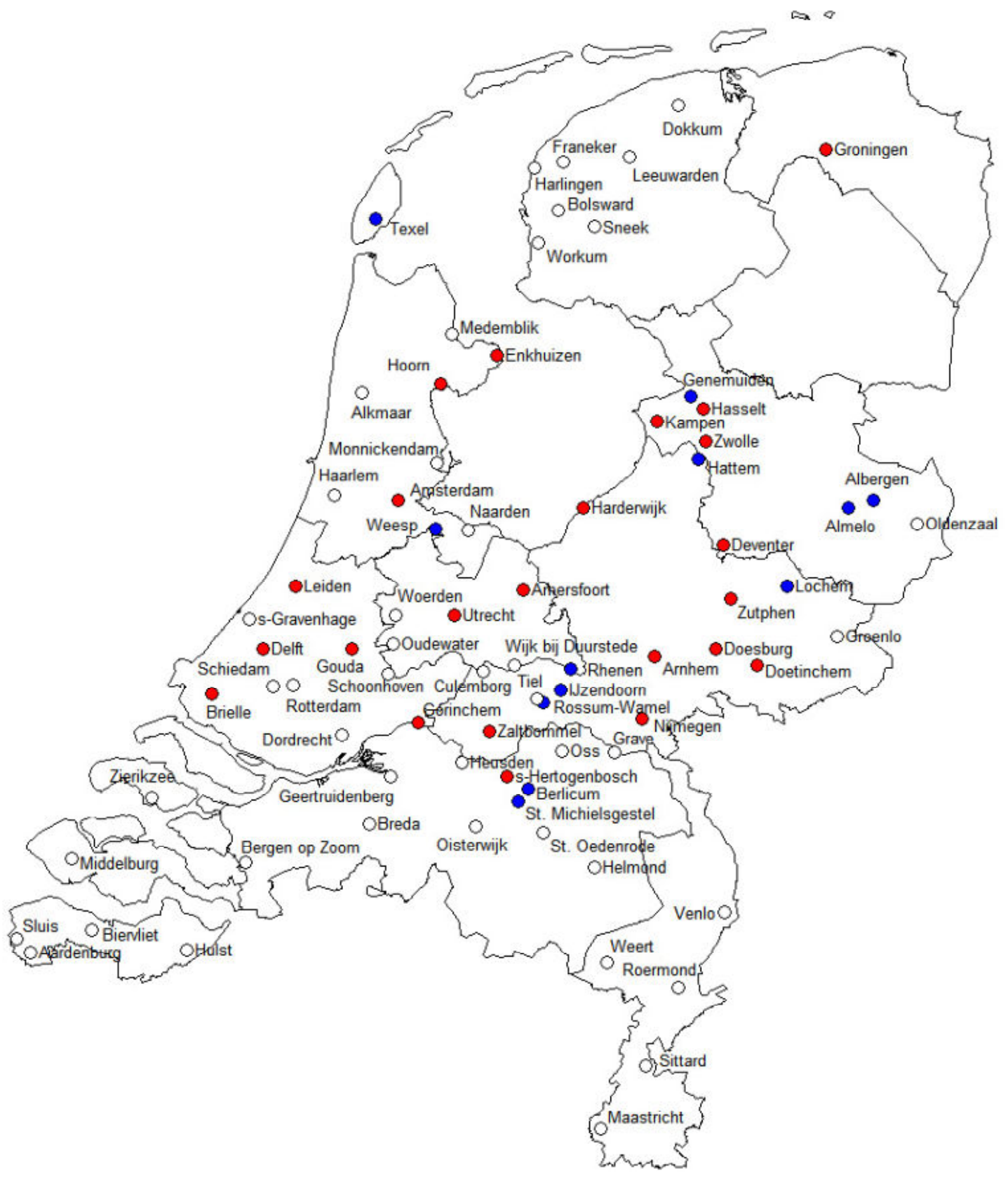

Note: Red dots are the BCL-cities with 1,000 or more inhabitants in 1400. These are used in the empirical analyses. Blue dots are small BCL-cities for which no further information is available. White dots are the other large cities in the Netherlands in 1400. $n=67$, with 23 large BCL cities, 12 small BCL-cities and 44 large nonBCL-cities. See Appendix A.2.3 for more details. 


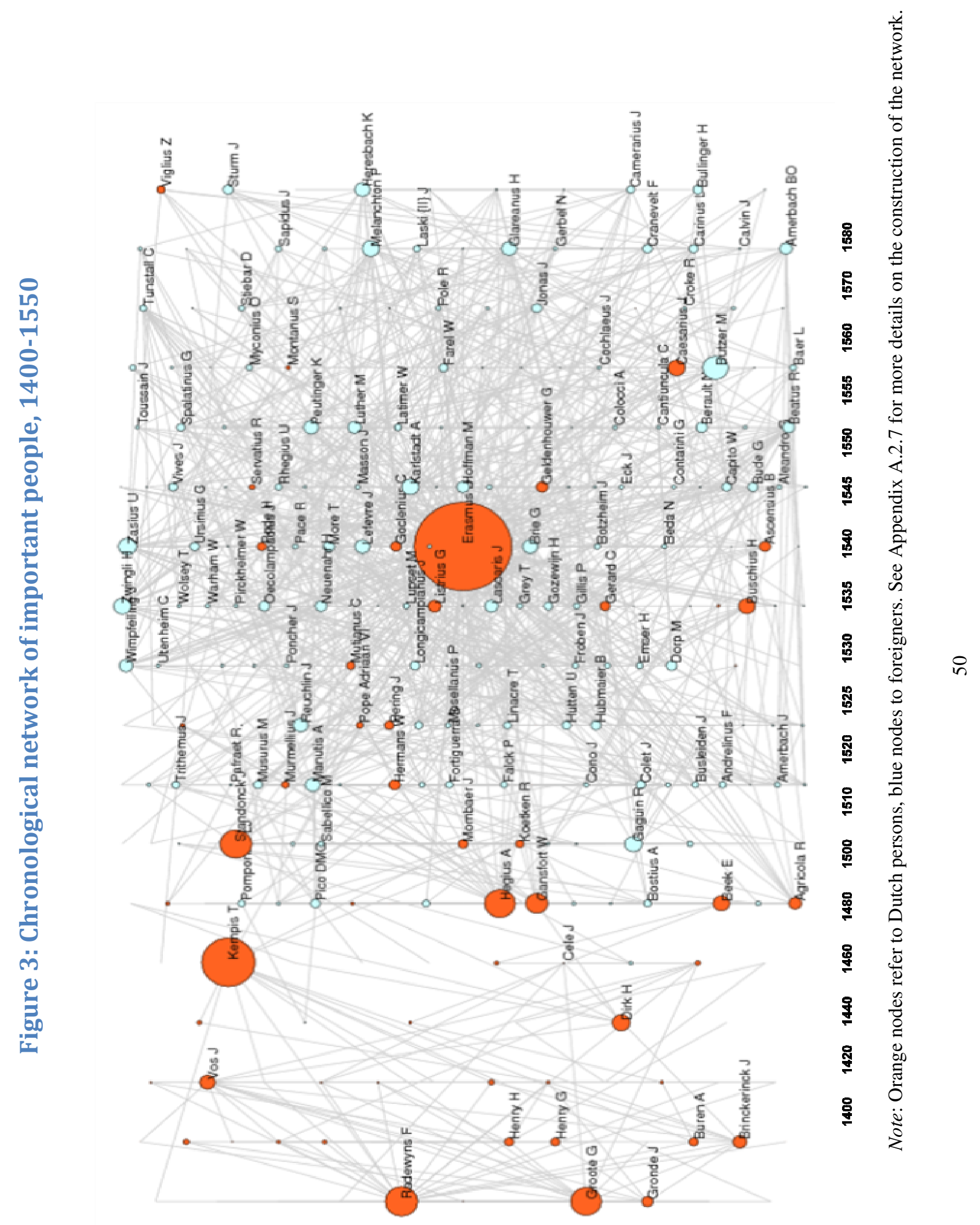




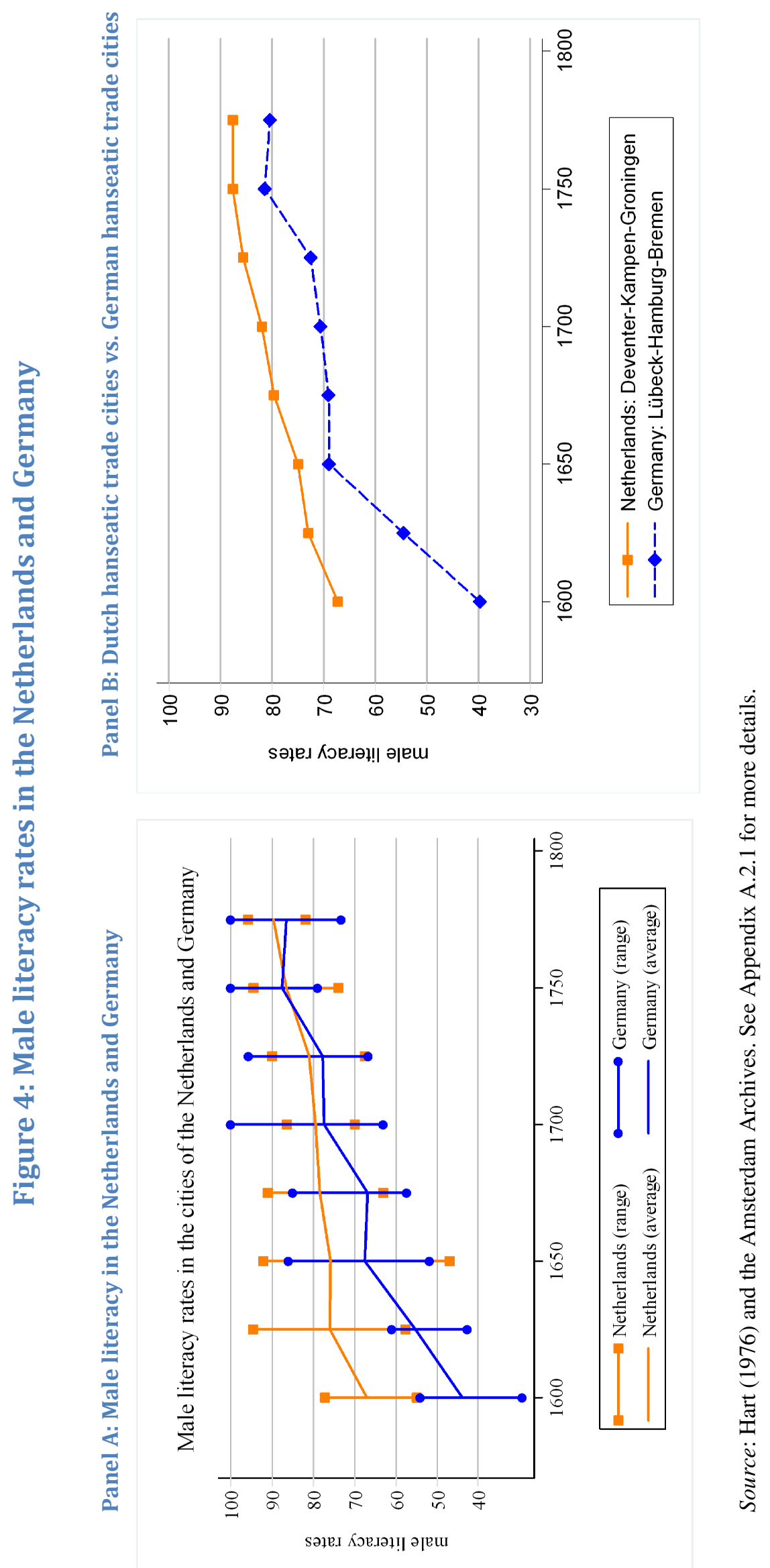


Figure 5: The diffusion of the Dutch Revolt in the Netherlands

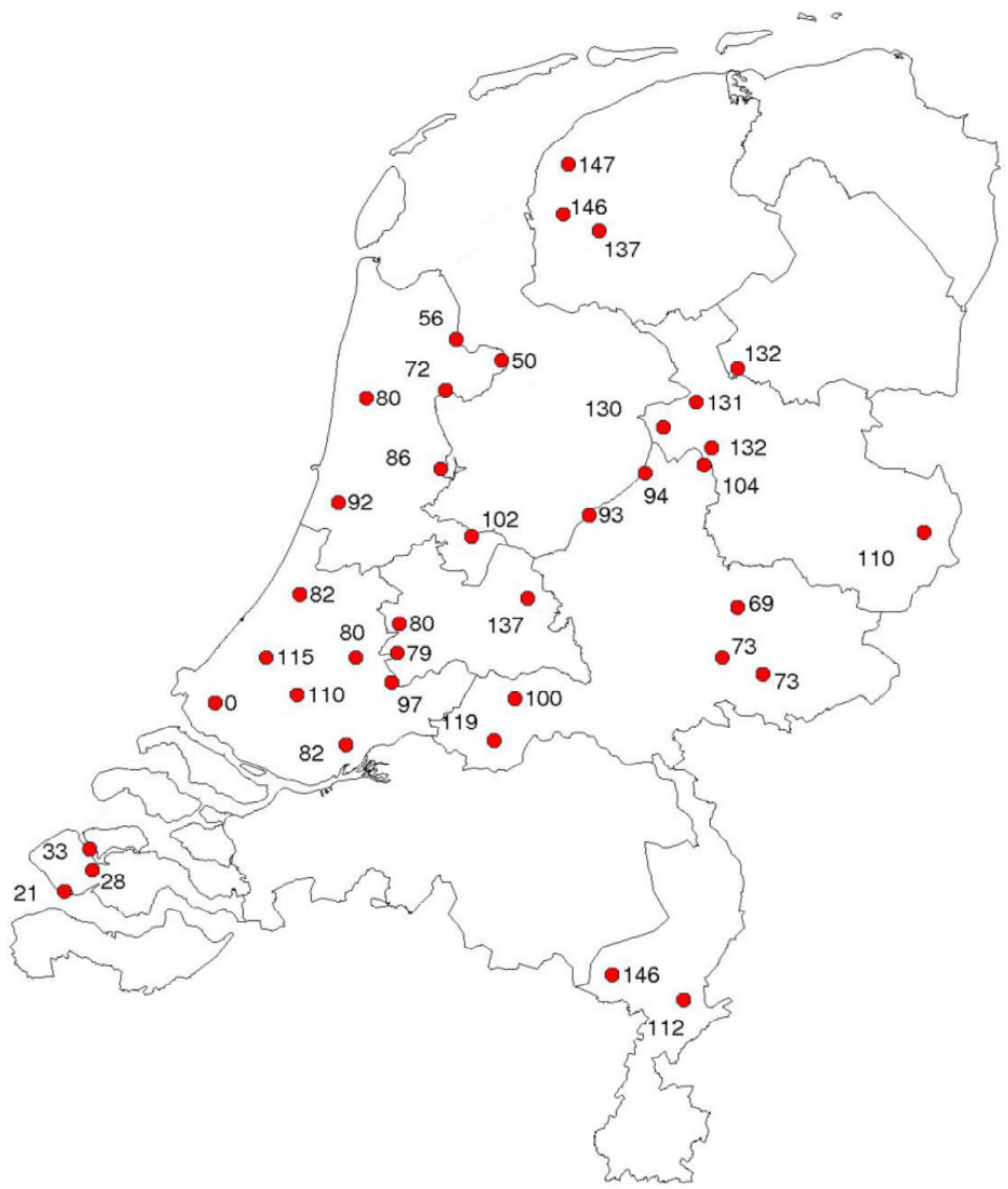

Note: The list of cities is presented in the Appendix (Section A.2.4). The dots are the 38 cities for which historical records about revolt dates are known. The numbers show the lag in days in terms of diffusion from 1 April 1572 onwards. For example, the observation 0 is Brielle where the Revolt started and 132 is Zwolle in which the Revolt started on 11 August 1572. 
Figure 6: Literacy and the Dutch Revolt

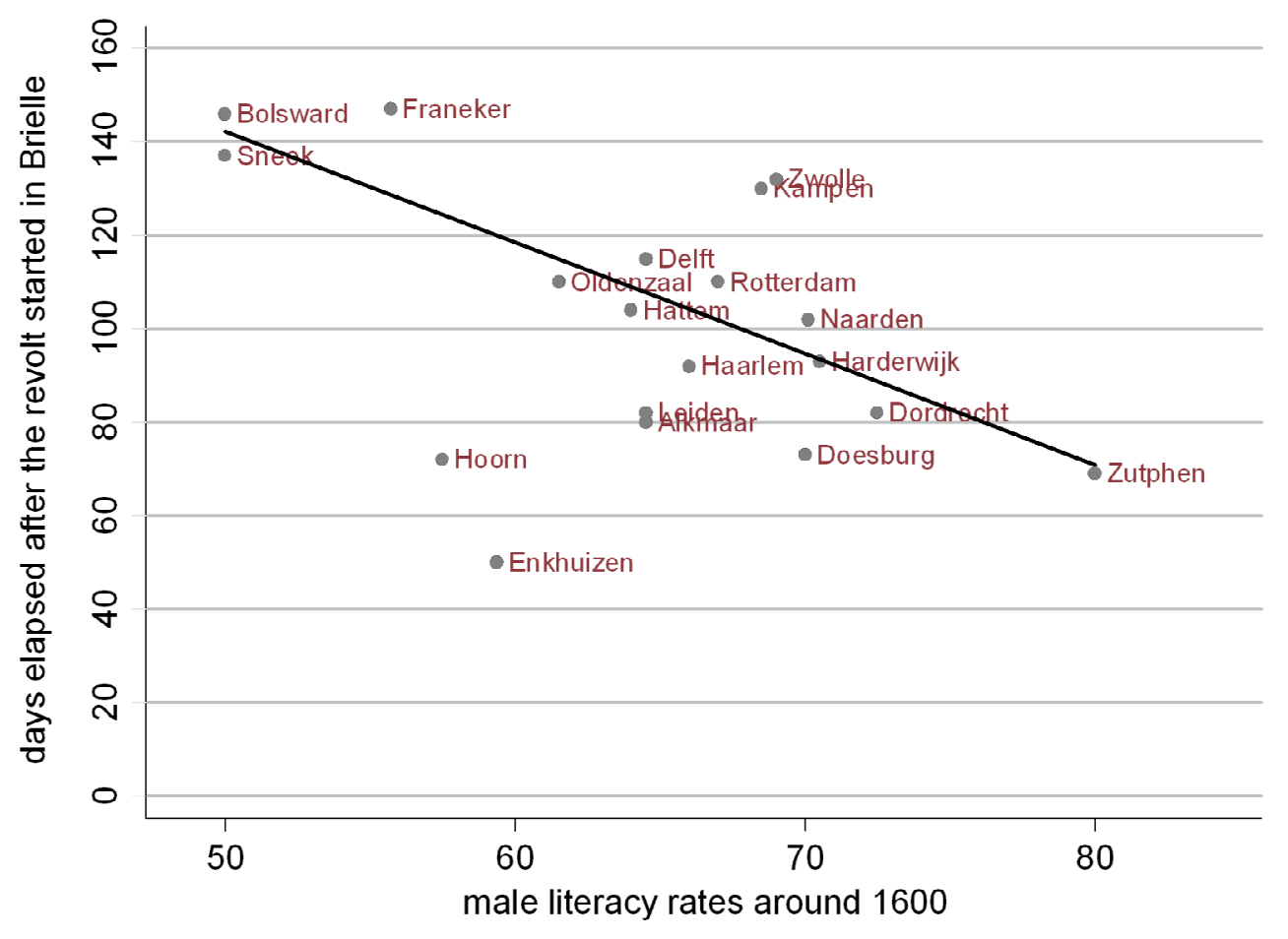

Note: $n=19$ of which 10 are BCL-cities. The coefficient (standard error) of the slope from an OLS regression model with the Revolt as the dependent variable equals -2.37 (0.329). 


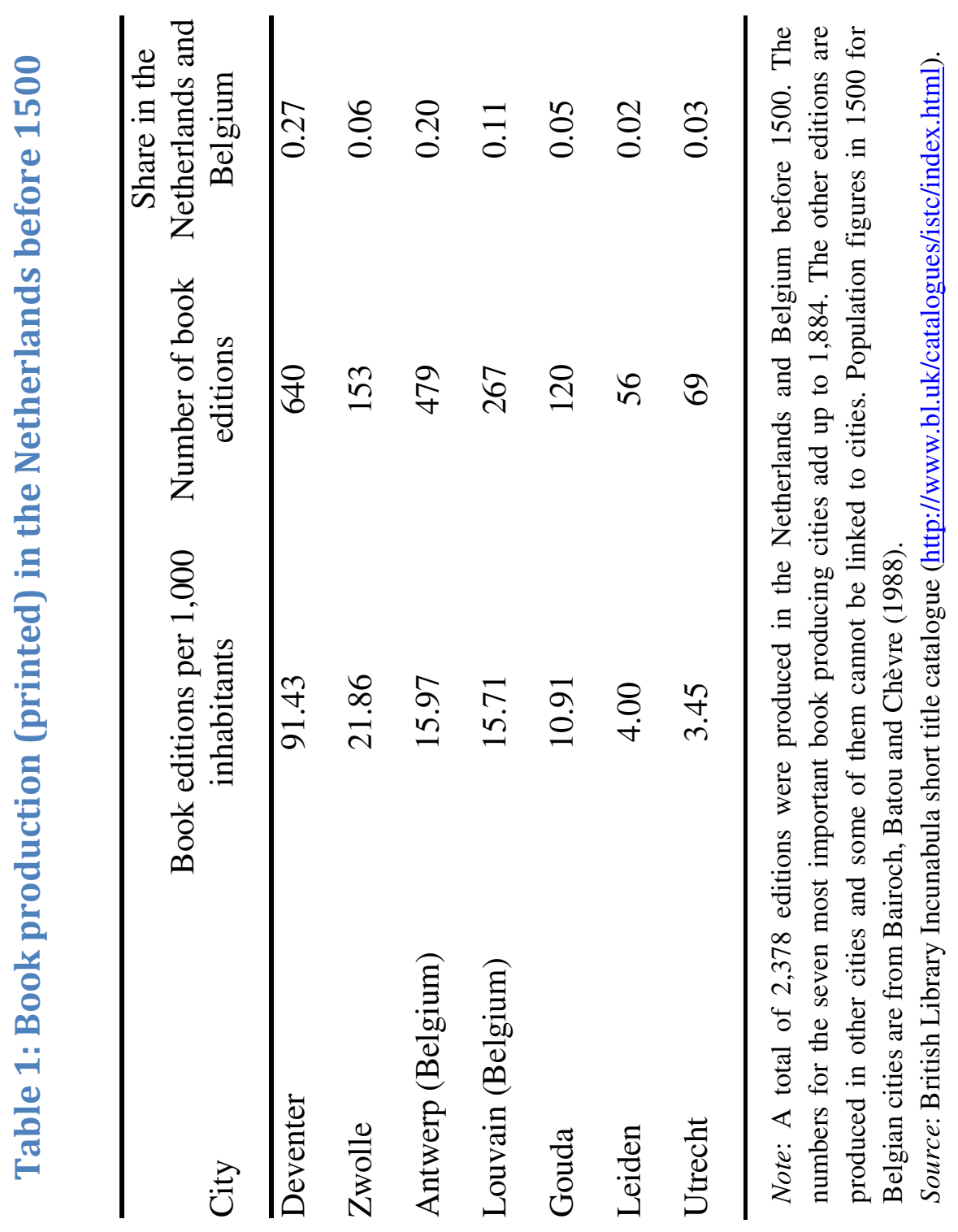




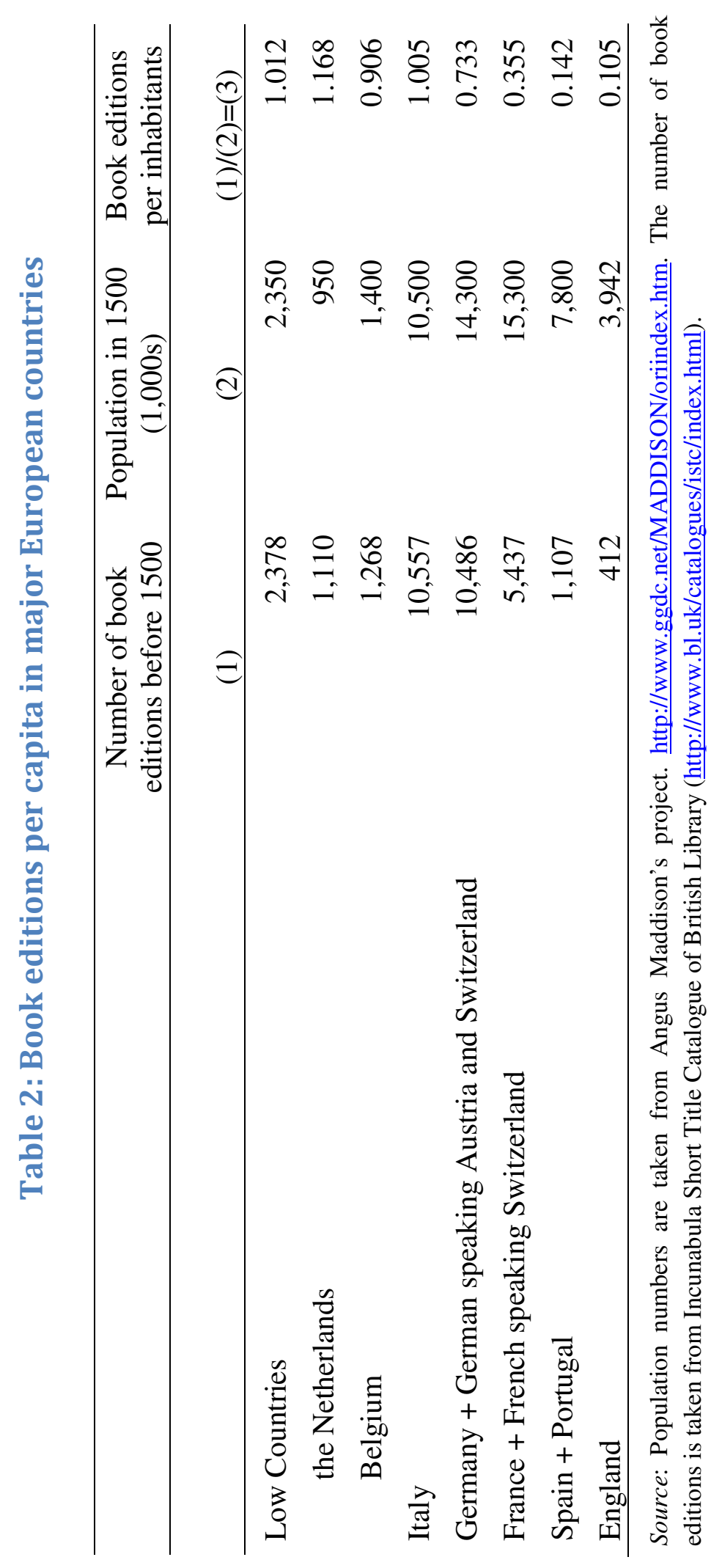

n 


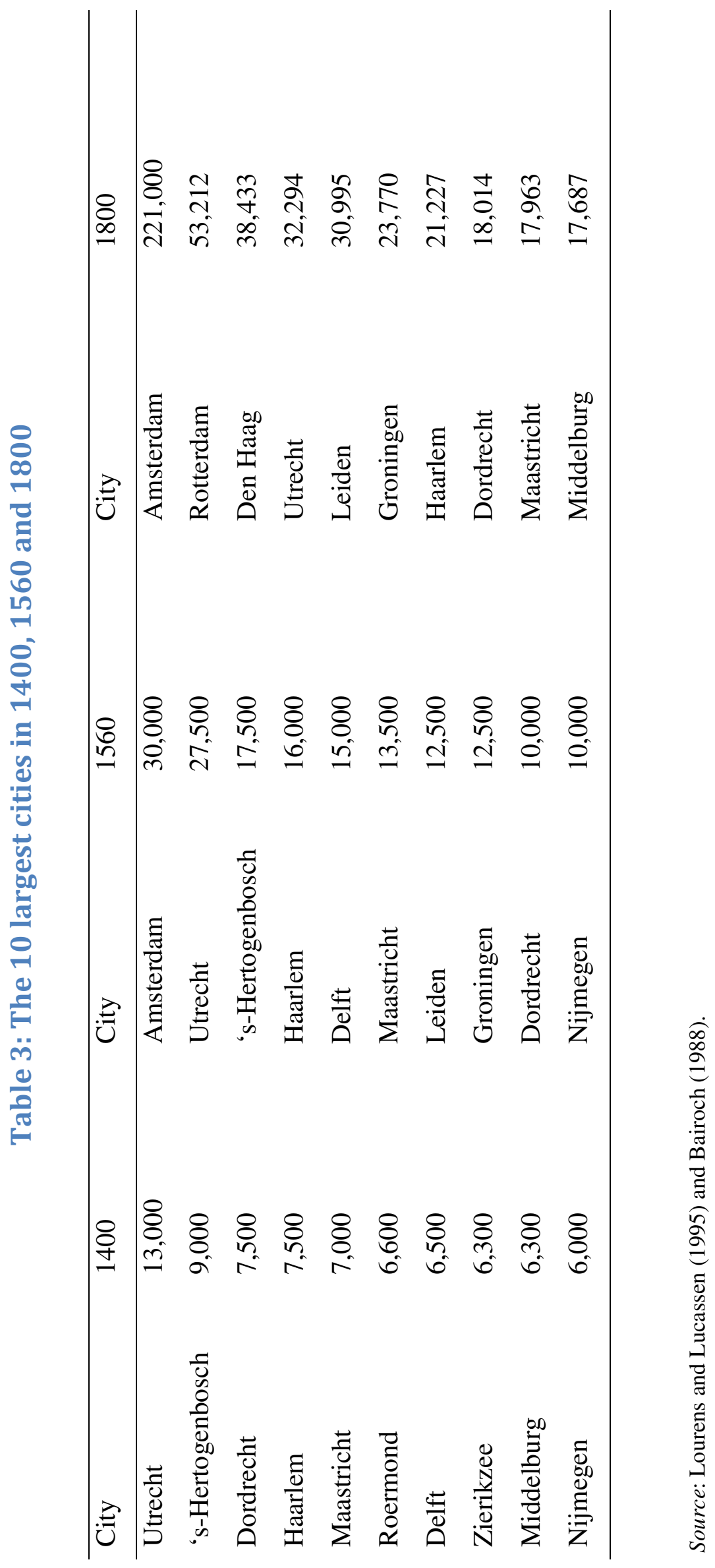

ถ 


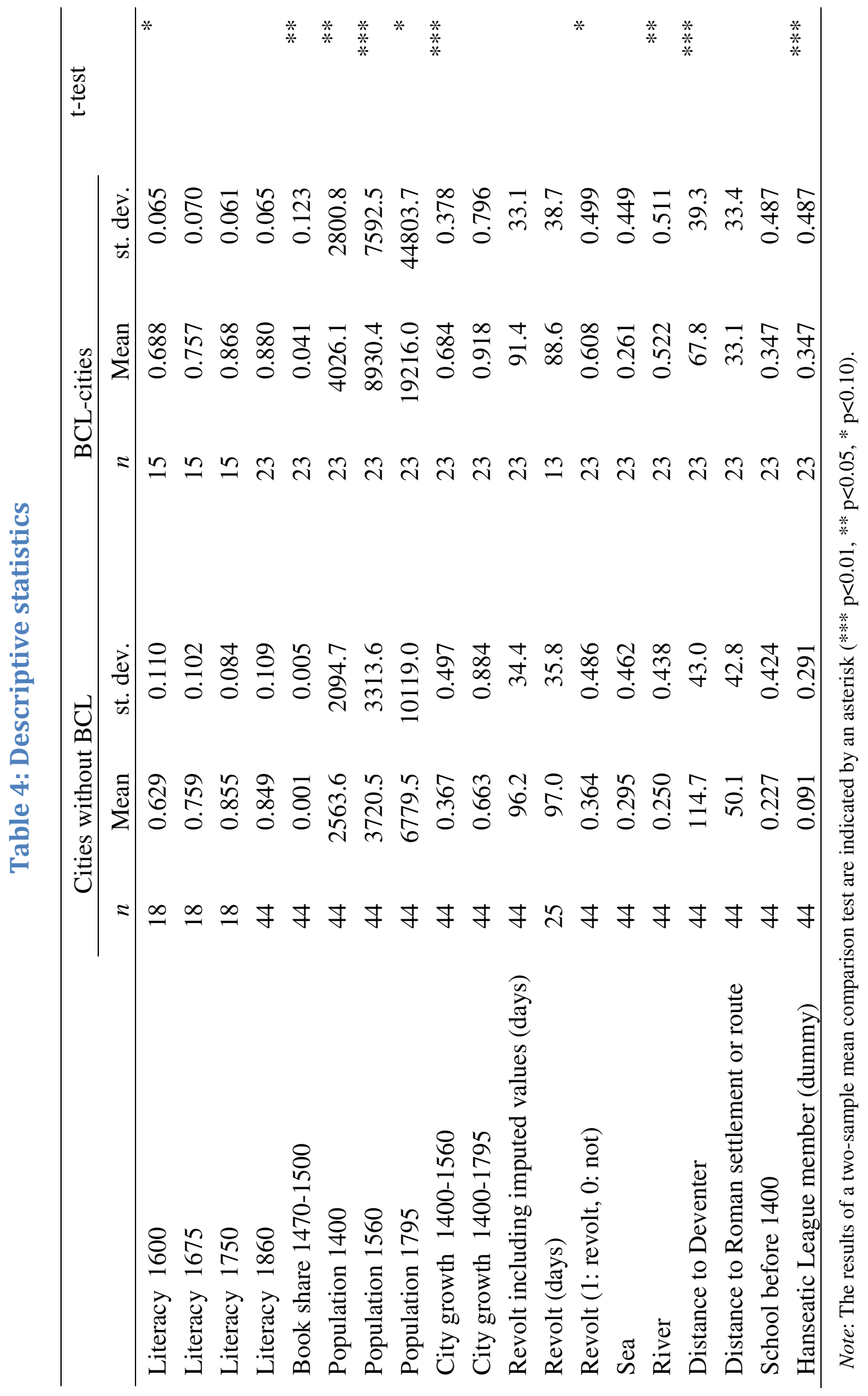




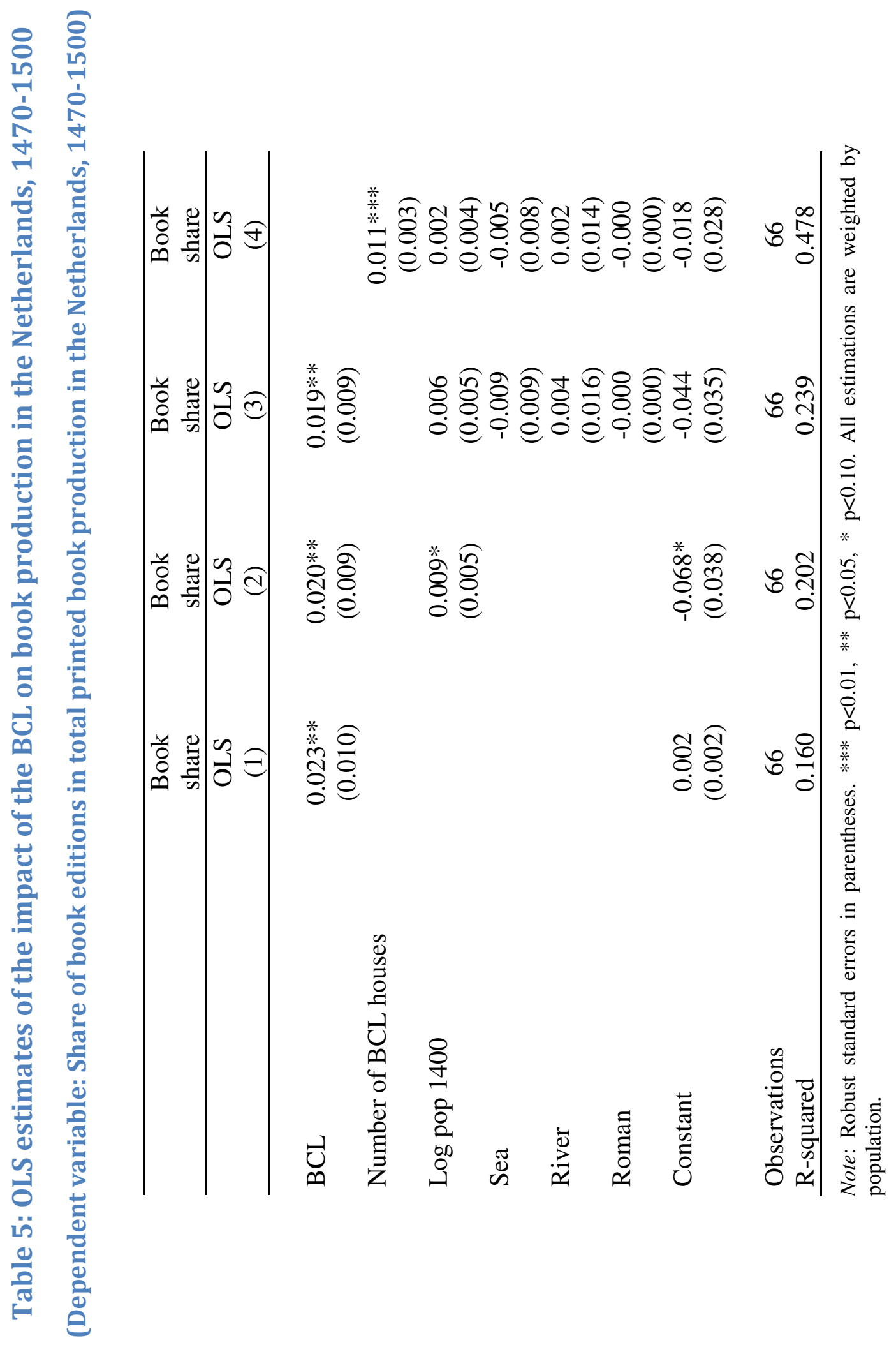




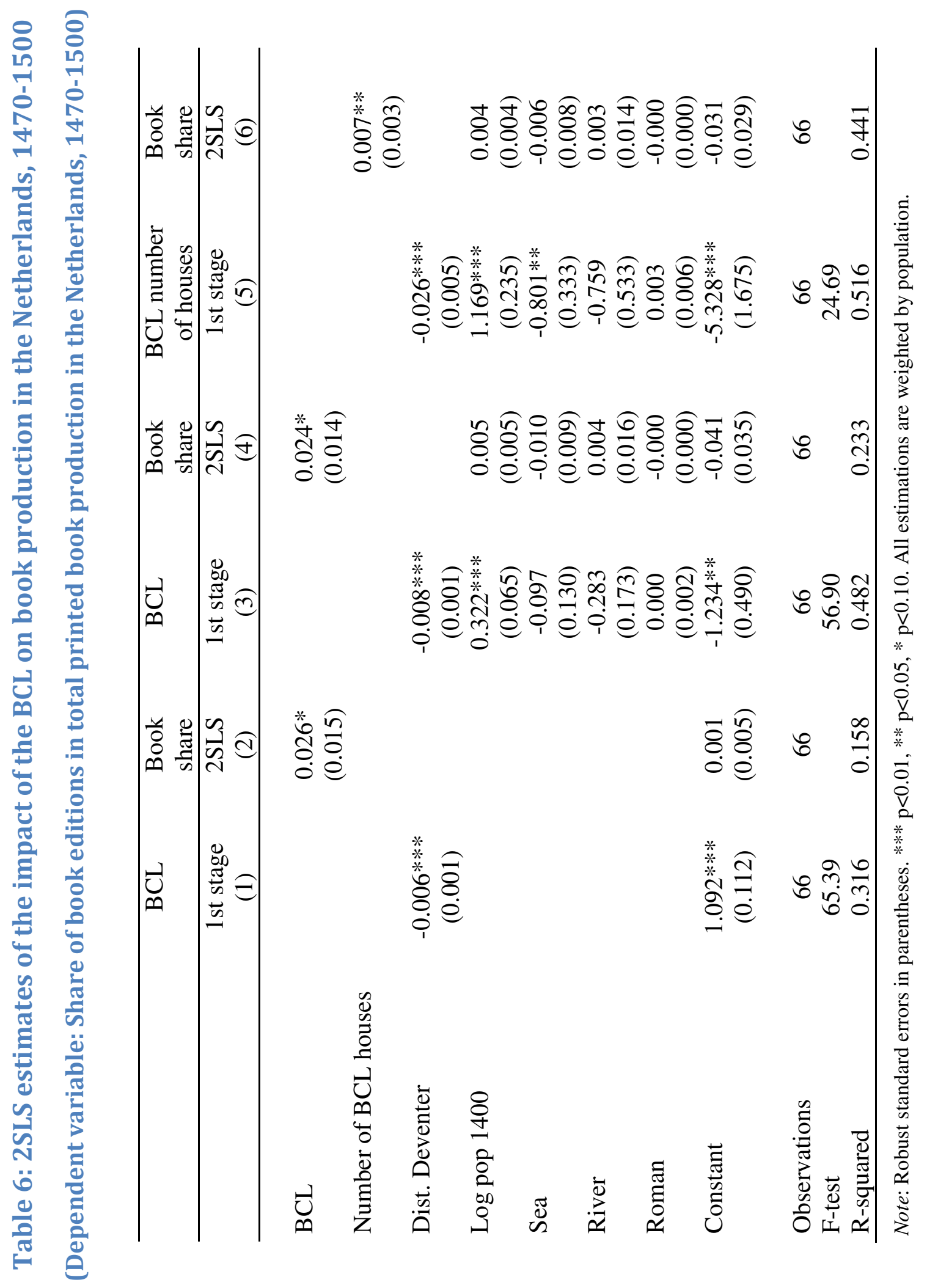




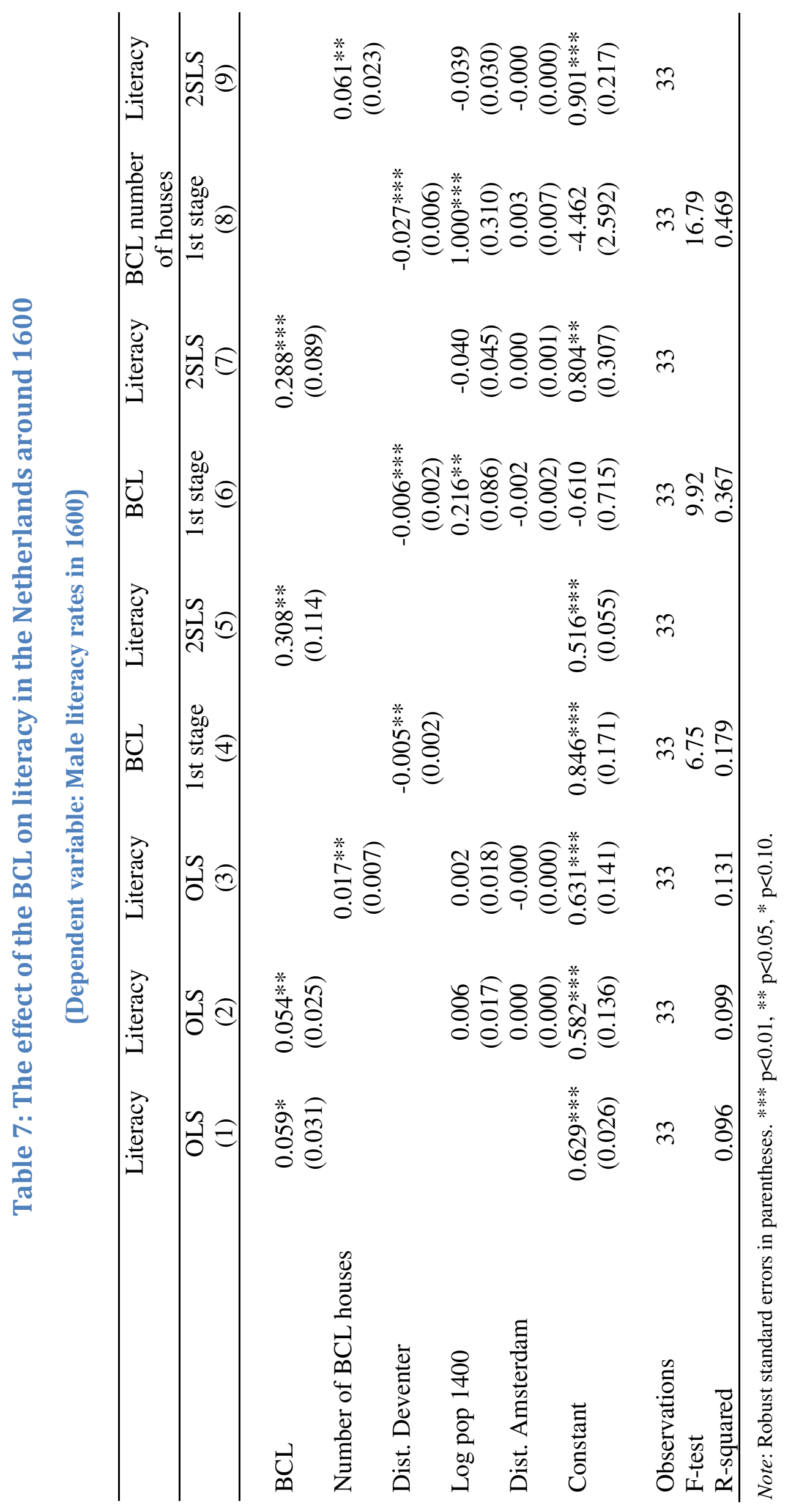




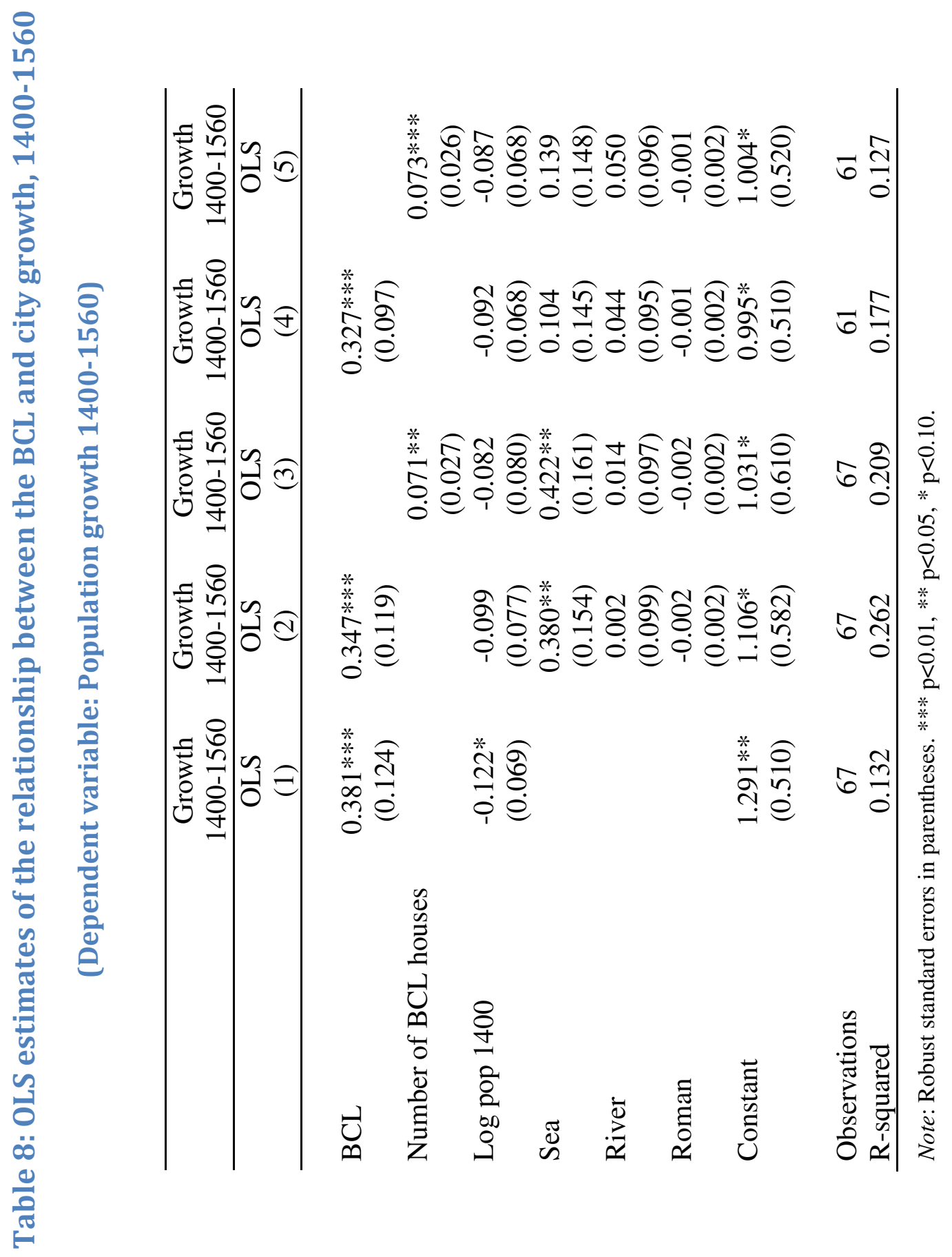




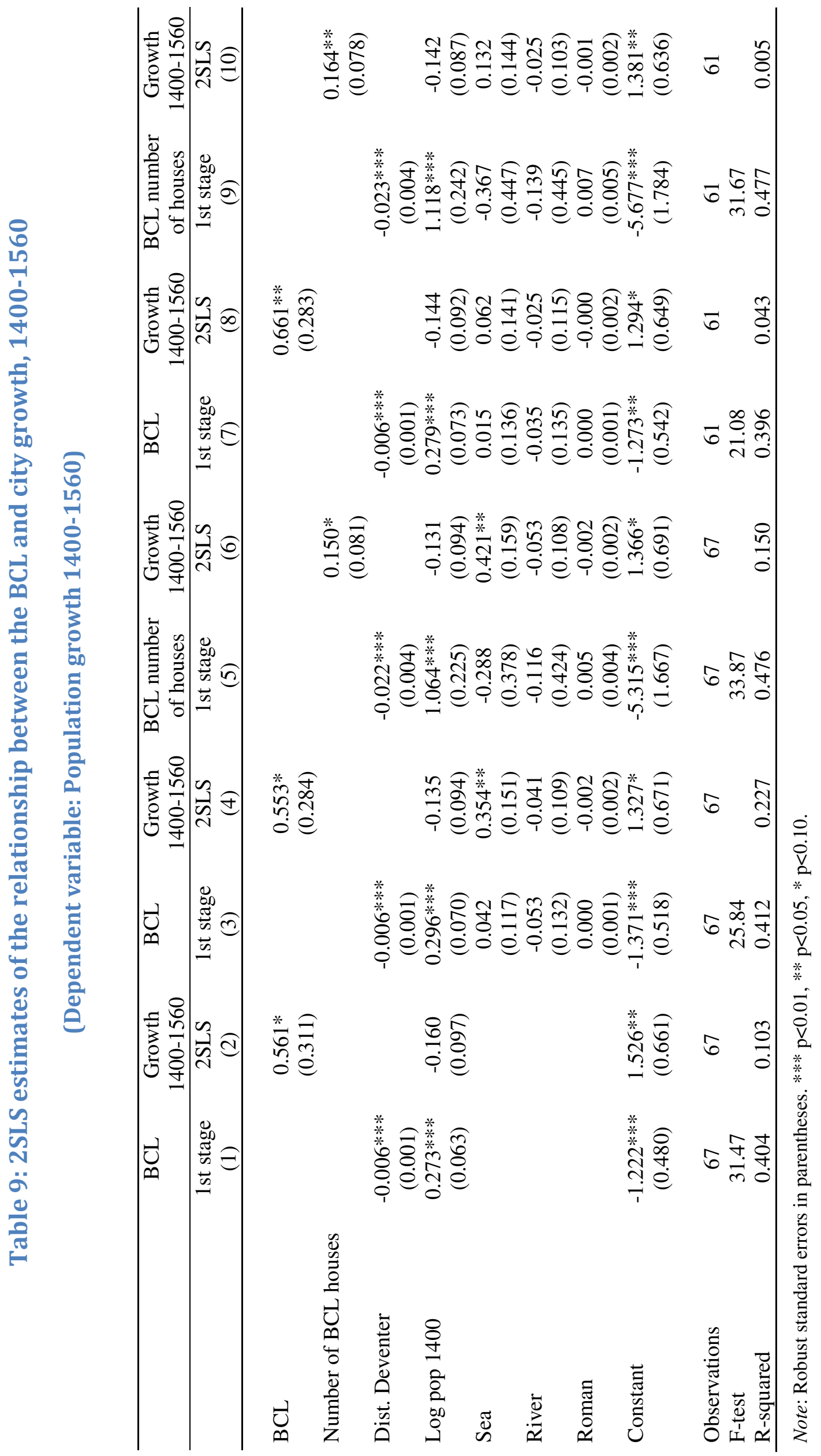




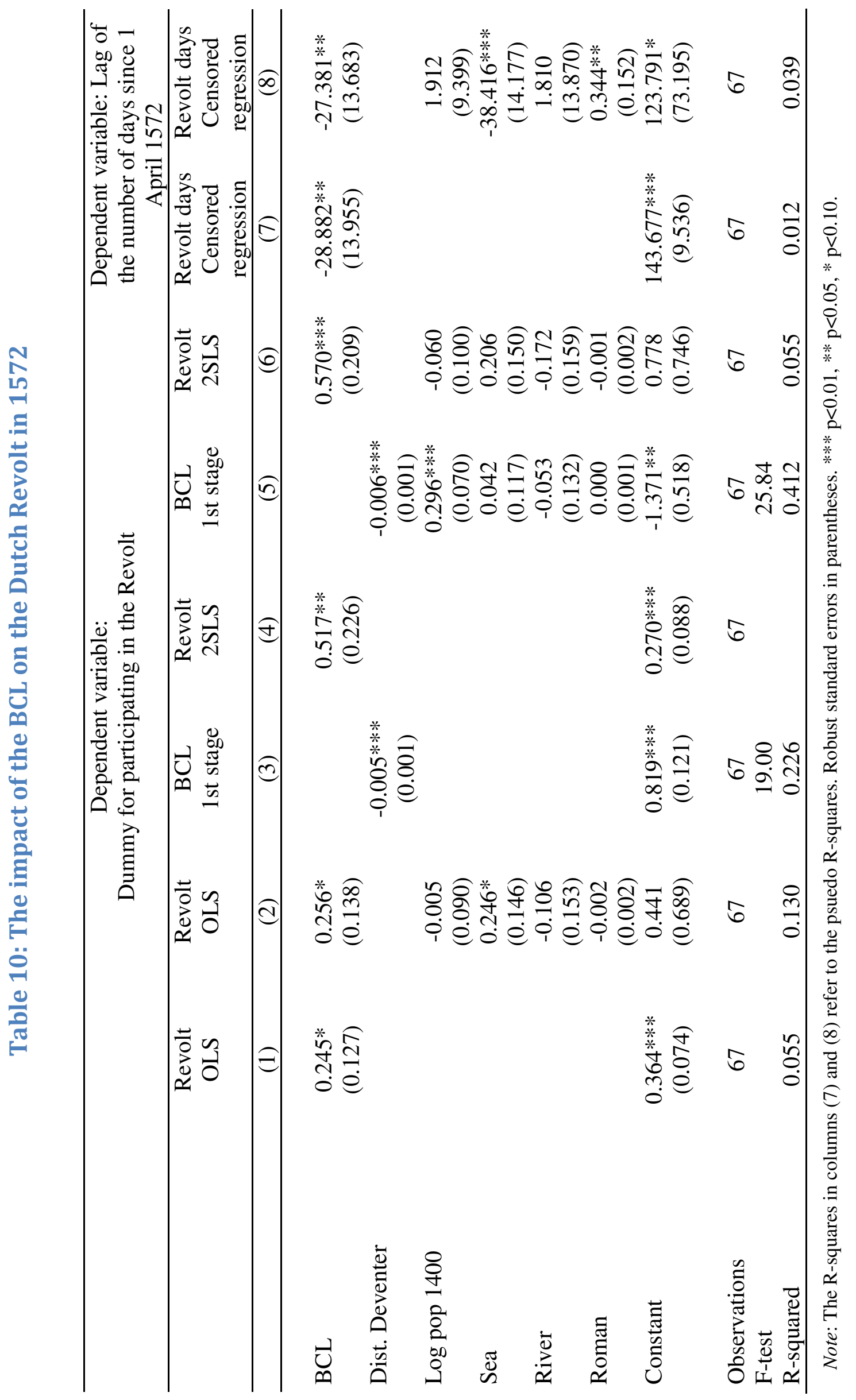




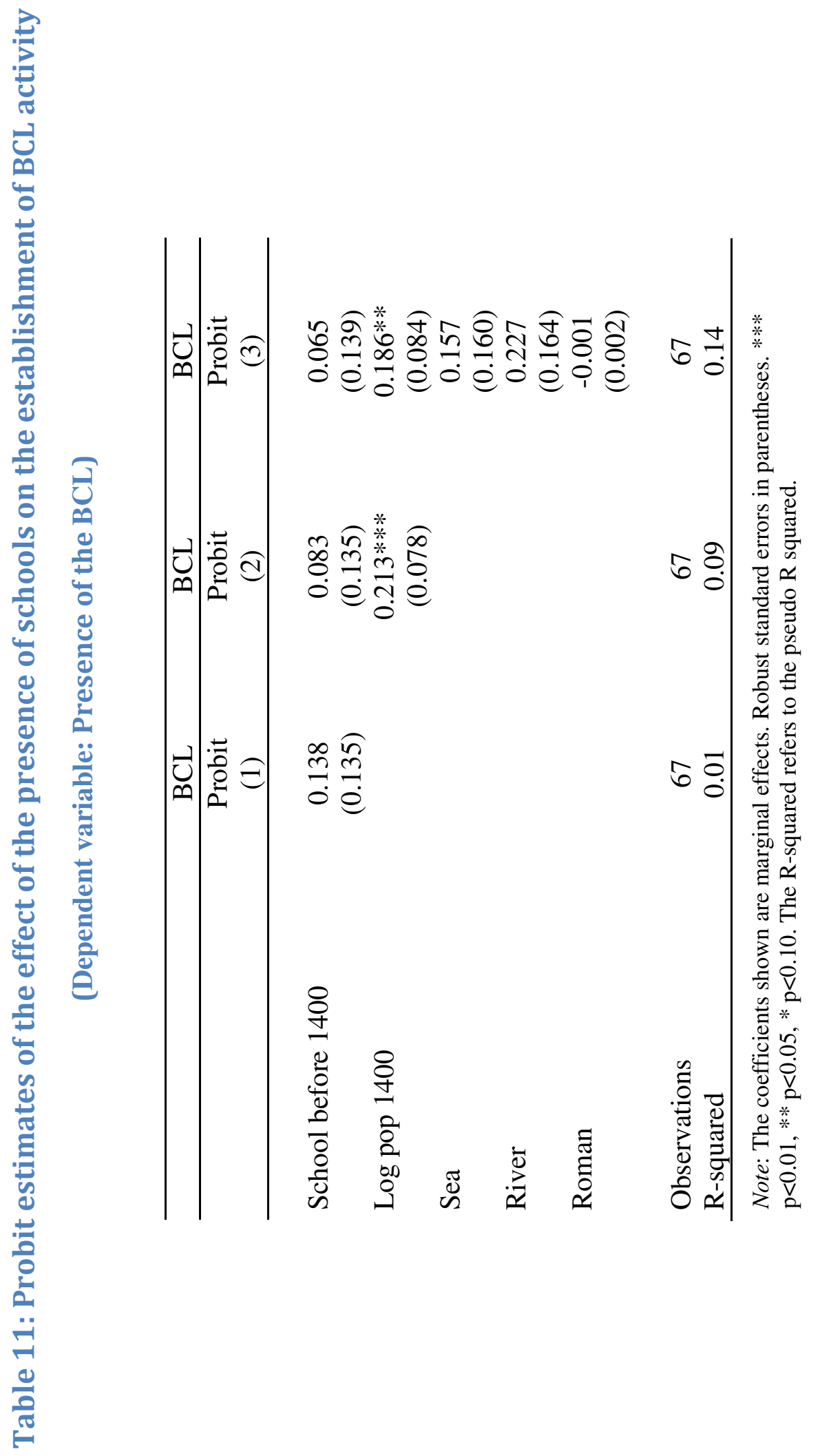




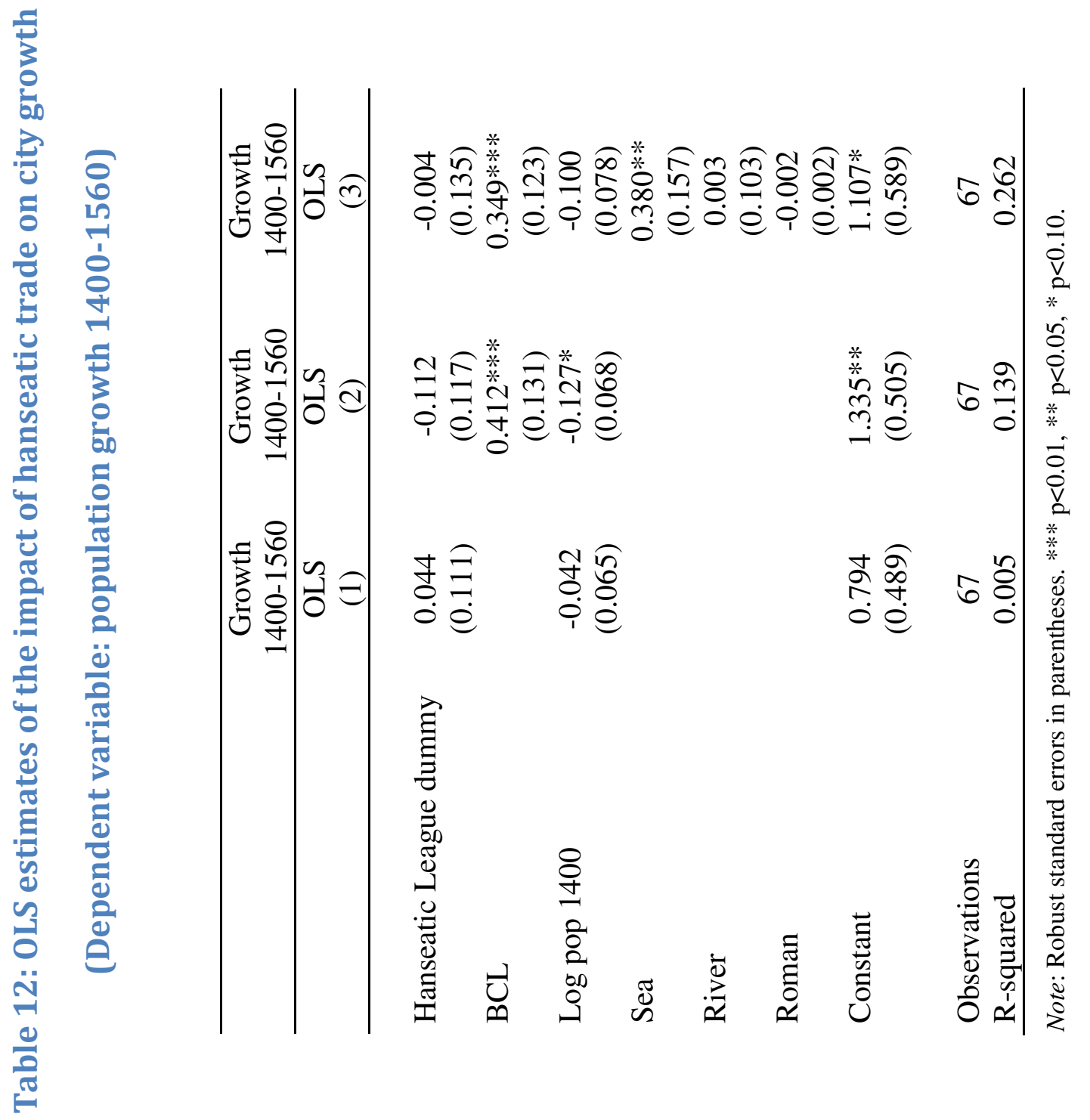




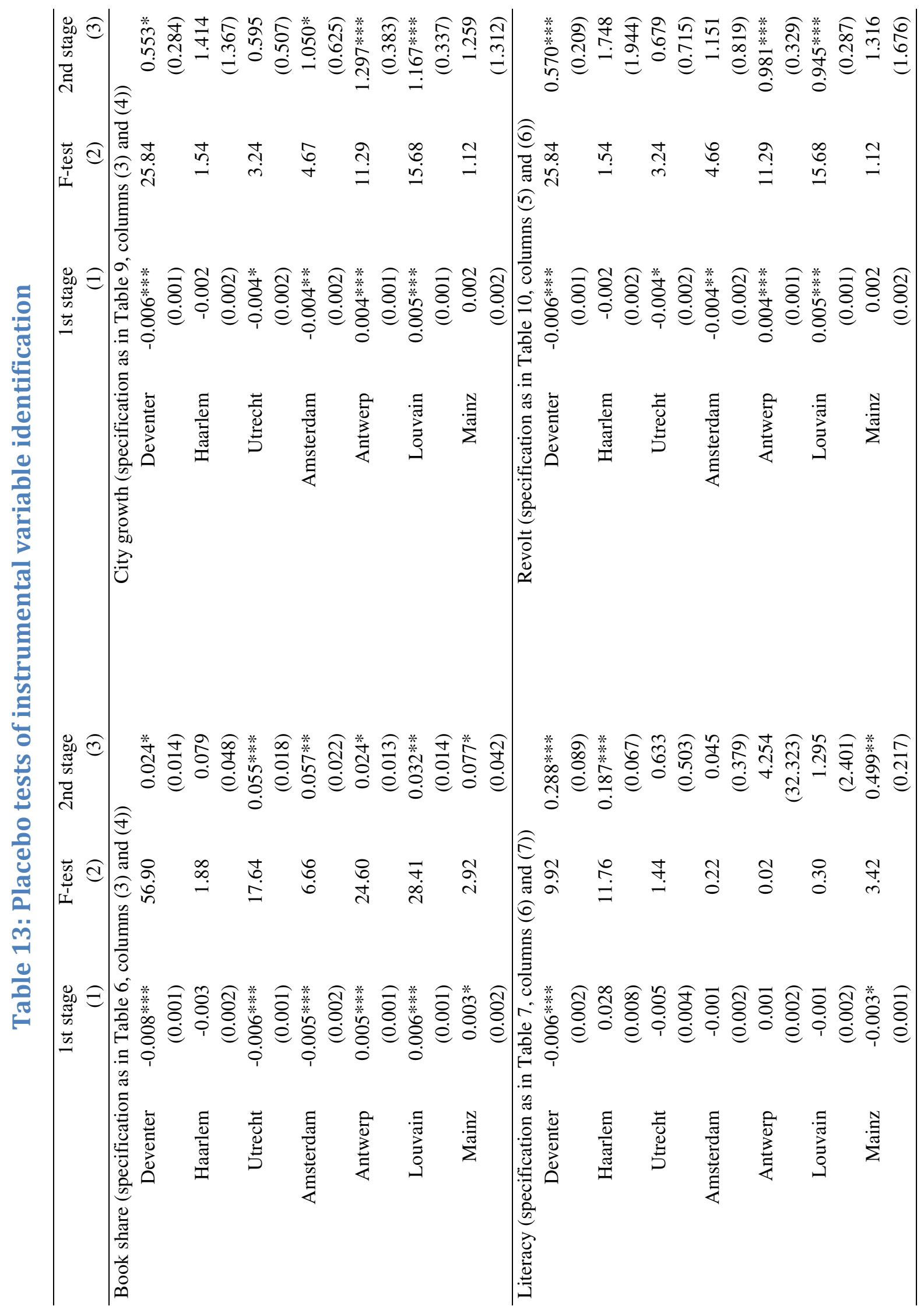




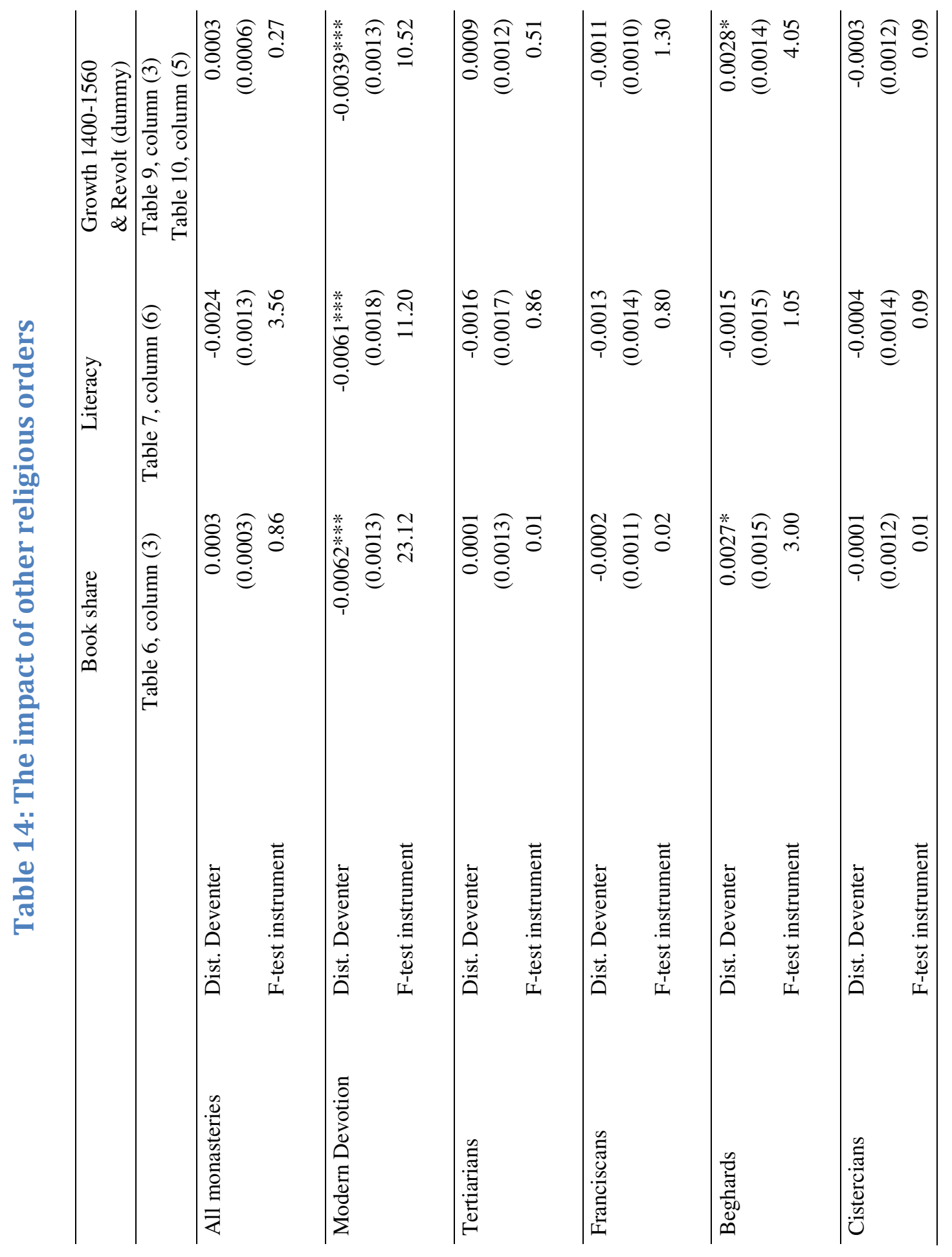




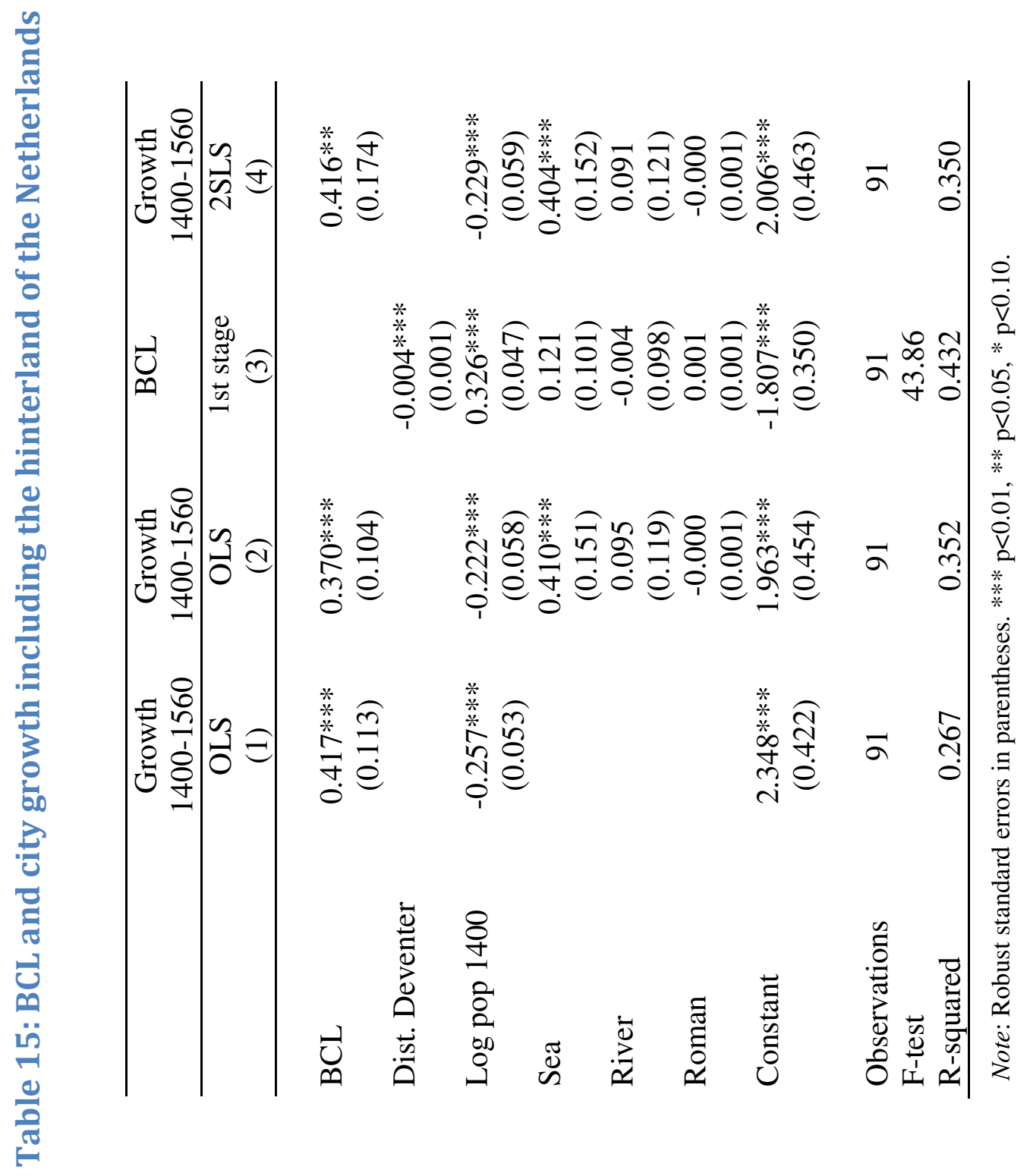




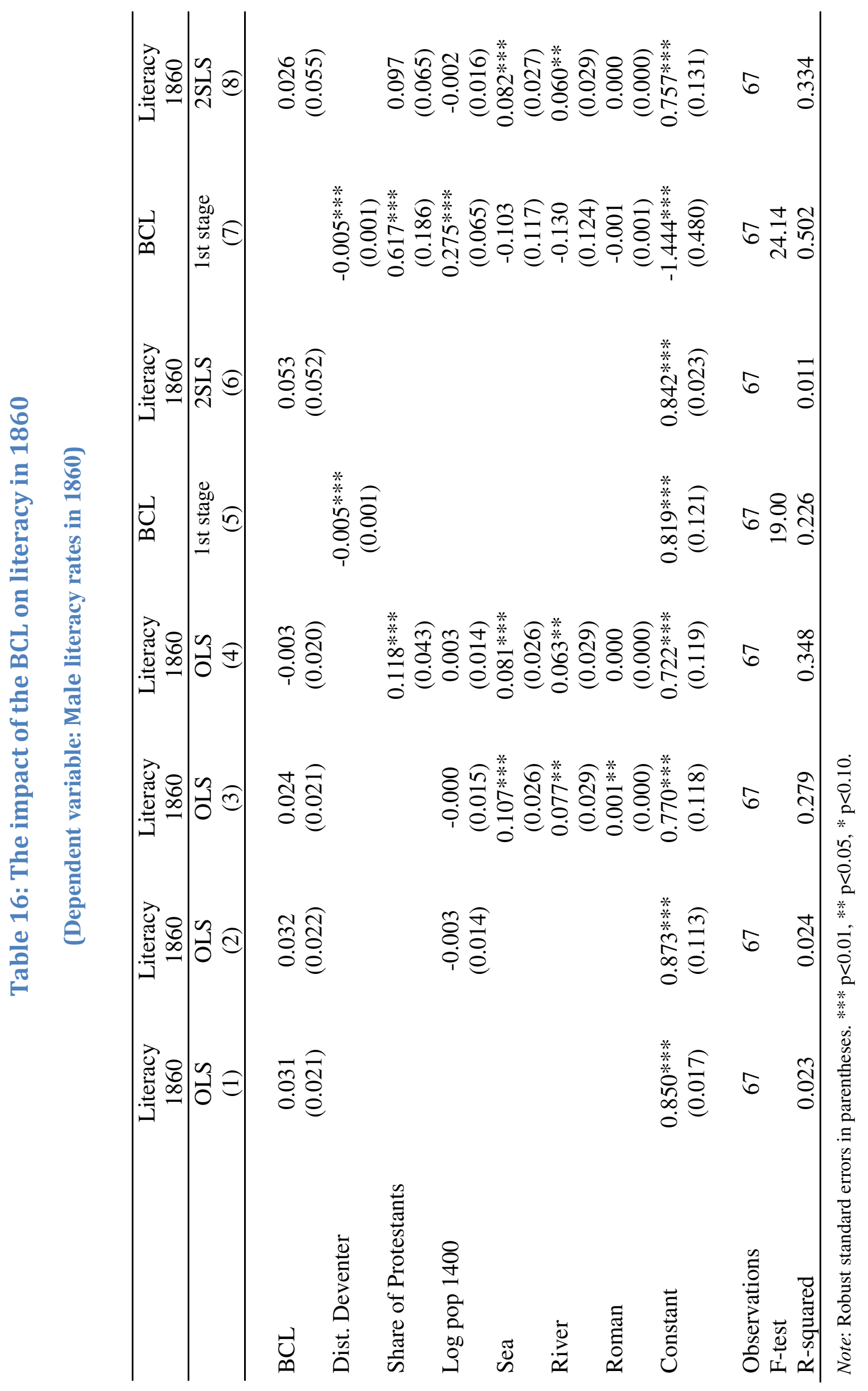




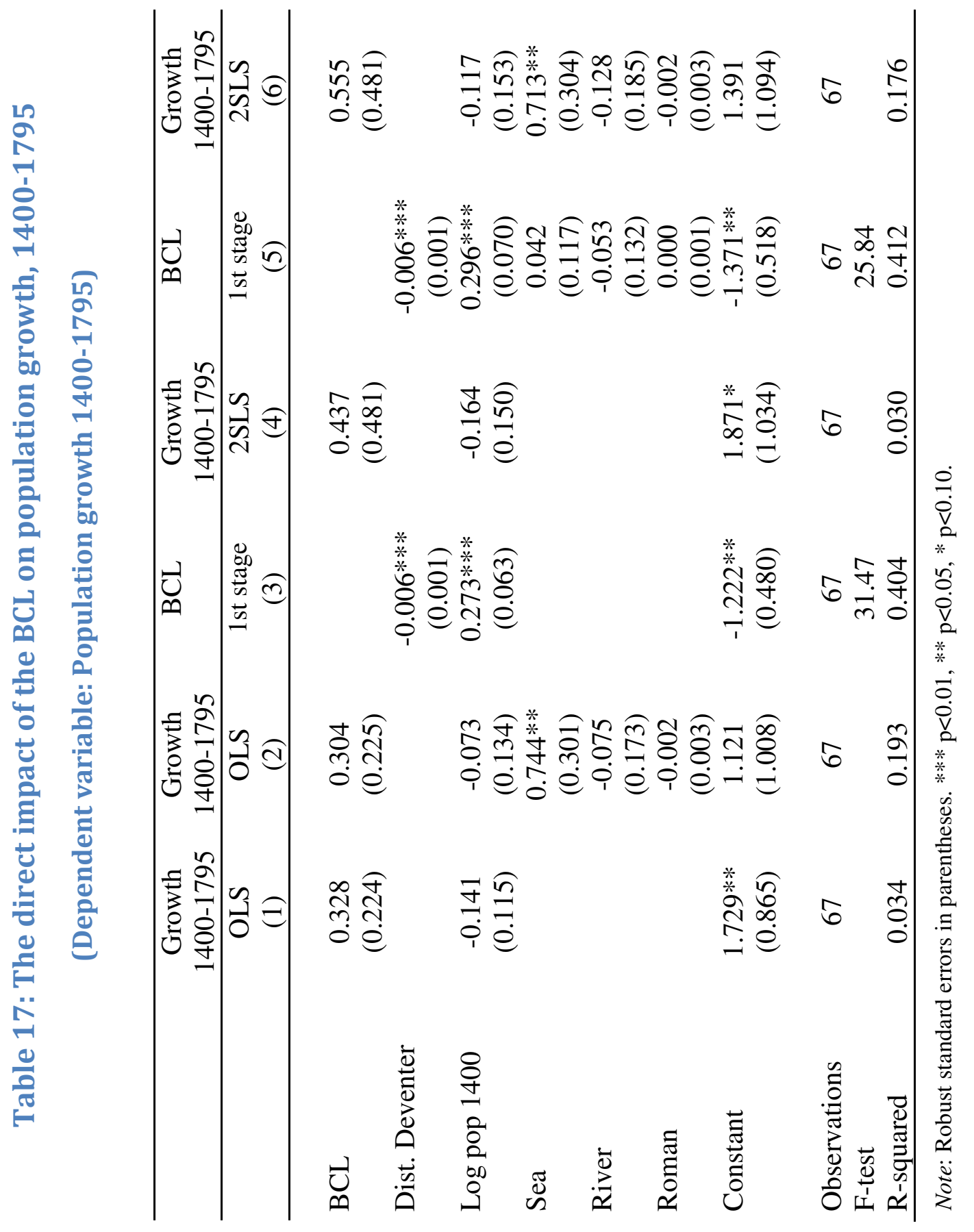

